Canadian

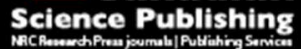

Canadian Journal of Forest Research Revue canadienne de recherche forestière

\title{
Patterns of bryophyte succession in a 160 year chronosequence in deciduous and coniferous forests of boreal Alaska
}

\begin{tabular}{|r|l|}
\hline Journal: & Canadian Journal of Forest Research \\
\hline Manuscript ID & cjfr-2017-0013.R1 \\
\hline Manuscript Type: & Article \\
\hline Date Submitted by the Author: & 20 -Mar-2017 \\
\hline Complete List of Authors: & $\begin{array}{l}\text { Jean, Mélanie; University of Saskatchewan, Department of Biology } \\
\text { Alexander, Heather; Mississippi State University, College of Forest } \\
\text { Resources, Forest and Wildlife Research Center } \\
\text { Mack, Michelle; Northern Arizona University, Center for Ecosystem Science } \\
\text { and Society and Department of Biological Sciences } \\
\text { Johnstone, Jill; University of Saskatchewan }\end{array}$ \\
\hline Keyword: & Boreal Forest, Succession, Moss, Chronosequence, Leaf litter \\
\hline $\begin{array}{r}\text { Is the invited manuscript for } \\
\text { consideration in a Special } \\
\text { Issue? : }\end{array}$ & N/A \\
\hline
\end{tabular}


1 Title: Patterns of bryophyte succession in a 160 year chronosequence in deciduous and 2 coniferous forests of boreal Alaska

3 Short title: Bryophyte succession in boreal Alaska

Authors and affiliations

6 Mélanie Jean

7 Department of Biology, University of Saskatchewan, Saskatoon, Saskatchewan S7N 5E2,

8 Canada

$9 \quad *$ corresponding author; e-mail: melanie.jean@usask.ca

Heather D. Alexander

Department of Forestry, College of Forest Resources, Forest and Wildlife Research Center,

13 Mississippi State University, MS 39762

Michelle C. Mack

16 Center for Ecosystem Science and Society and Department of Biological Sciences, Northern

17 Arizona University, Flagstaff, Arizona 86011, USA

Jill F. Johnstone

Department of Biology, University of Saskatchewan, Saskatoon, Saskatchewan S7N 5E2,

21 Canada

\section{Roles}

MJ lead the 2013-2015 field and laboratory work, data analysis and drafted the manuscript with guidance from HDA, MCM, and JFJ. MCM and JFJ developed the field methods and initiated the sampling. HDA lead the 2008-2010 field and laboratory work. MCM and JFJ provided advice on data collection and research questions, and all authors provided input to this 28 manuscript. 


\section{Abstract}

32 Bryophytes are dominant components of boreal forest understories and play a large role in 33 regulating soil microclimate and nutrient cycling. Therefore, shifts in bryophyte communities

34 have the potential to affect boreal forests' ecosystem processes. We investigated how bryophyte 35 communities varied in 83 forest stands in interior Alaska that ranged in age (since fire) from 8-

36163 years, and had canopies dominated by deciduous broadleaf (Populus tremuloides or Betula

37 neoalaskana) or coniferous trees (Picea mariana). In each stand, we measured bryophyte

38 community composition, along with environmental variables (e.g. organic layer depth, leaf litter

39 cover, moisture). Bryophyte communities were initially similar in deciduous vs. coniferous

40 forests, but diverged in older stands in association with changes in organic layer depth and leaf

41 litter cover. Our data suggest two tipping points in bryophyte succession: one at the

42 disappearance of early colonizing taxa 20 years after fire, and another at 40 years after fire,

43 which corresponds to canopy closure and differential leaf litter inputs in mature deciduous and

44 coniferous canopies. Our results enhance understanding of the processes that shape

45 compositional patterns and ecosystem services of bryophytes in relation to stand age, canopy

46 composition, and changing disturbances, such as fire, that may trigger changes in canopy

47 composition.
Keywords Boreal Forest Succession Moss Chronosequence Leaf litter Canopy effects Fire Bryophyte 


\section{Introduction}

In high latitude ecosystems such as boreal forests, bryophytes (mosses, liverworts, and

61 hornworts) are dominant and ubiquitous components of the understory and account for a

62 significant proportion of plant diversity (Turetsky et al. 2012). Boreal ecosystems are also

63 characterized by large stand-replacing fires, which trigger successional changes in bryophyte

64 communities. General patterns of post-fire bryophyte regeneration have been investigated in

65 coniferous stands (Foster 1985, Turetsky et al. 2010, Fenton and Bergeron 2013), where

66 colonization, competition (Rydin 1997) and facilitation (Fenton and Bergeron 2006) are known

67 to be important in shaping bryophyte succession. However, the boreal forest is a mosaic also

68 composed of mixedwood and deciduous stands where bryophytes are less abundant, and

69 bryophyte succession is poorly documented (Hart and Chen 2006). Bryophyte roles have often

70 been overlooked in ecosystem studies, even though they can account for a surprisingly large

71 portion of net above-ground primary production and influence regulation of soil microclimate,

72 permafrost stability, nutrient cycling, and ground fuel loads (Turetsky et al. 2012). Knowledge of

73 where, when and why bryophyte communities change throughout succession is an important gap

74 in our understanding of boreal ecosystem functioning.

Canopy composition in boreal forests is one of the major factors influencing understory

76 communities, including bryophytes (De Grandpré et al. 1993, Hart and Chen 2006). Thus, factors

77 that drive changes in canopy composition will likely cause concomitant changes in bryophyte

78 communities. Changes in the fire regime associated with recent climate warming in Alaska and

79 northwestern Canada are predicted to have dramatic impacts on succession, composition, and

80 structure of boreal forest ecosystems (Johnstone et al. 2010a, Johnstone et al. 2010b). For

81 example, increases in fire severity that more fully combust bryophyte and organic soil layers 
82 have caused recruitment of canopy species to shift from dominant conifer species such as black

83 spruce (Picea mariana Mill B.S.P.) to alternate deciduous species such as Alaska paper birch

84 (Betula neoalaskana Sarg.) and trembling aspen (Populus tremuloides Michx.) (Johnstone et al.

85 2010b). Shifts from conifer to deciduous dominance may affect bryophyte communities because

86 the high inputs of leaf litter and warm, dry soils characteristic of deciduous forests are

87 hypothesized to reduce bryophyte abundance (Van Cleve and Viereck 1981, Hart and Chen

88 2006). Changing bryophyte communities as a consequence of shifting forest dominance could

89 affect key processes, such as nutrient cycling, soil temperature, and vascular plant recruitment

90 (Hart and Chen 2006).

91 In this context, understanding bryophyte succession under alternate pathways of canopy

92 succession in boreal forests will provide insight into possible driving mechanisms of the different

93 patterns of composition and ecosystem function found in mature deciduous and coniferous

94 forests (Van Cleve and Viereck 1981, Johnstone et al. 2010a). Currently it remains unclear

95 whether contrasting bryophyte communities in mature stands develop from diverging or

96 completely distinct successional trajectories in deciduous and coniferous stand types. Distinct

97 successional trajectories could be caused by initial differences that persist through time, such as

98 legacies from fire severity, colonization, or site-specific characteristics (Foster 1985, Hart and

99 Chen 2006, Turetsky et al. 2012). Diverging successional trajectories of bryophytes, where

100 community composition is similar early in succession, but forms distinct bryophyte associations

101 as stand age, may be caused by canopy-driven changes in processes such as light transmission,

102 evapotranspiration, throughfall, or litter production (Van Cleve and Viereck 1981).

103 The purpose of this study was to examine patterns of post-fire bryophyte succession in

104 boreal forests dominated by coniferous or deciduous trees. We explicitly tested competing 
105 hypotheses of distinct or diverging trajectories of succession by testing for differences in

106 bryophyte abundance and species assemblages among forest canopy types in different

107 successional stages. We gathered data on bryophyte communities from stands in interior Alaska

108 that shared similar environmental conditions and pre-fire history, but ranged in post-fire age

109 from 8 to 163 years. We predicted that bryophyte cover and species assemblages would vary

110 with stand age and forest canopy type, but if bryophyte succession followed distinct patterns

111 among canopy types, these differences would appear early in succession, while divergent

112 succession processes would lead to differences in bryophyte cover and composition appearing

113 among canopy types only later in succession. By investigating how patterns of bryophyte

114 abundance change at different time points during succession and looking for overlap or

115 differences both in cover and species composition, we can differentiate between the two types of

116 succession. We used information on stand ages to identify time periods when divergence occurs,

117 if present, and investigated associations of environmental covariates with changes in bryophyte

118 communities to develop hypotheses of important factors shaping patterns of bryophyte

119 succession in deciduous and coniferous forest stands. Results of this study provide insights into

120 the processes that drive bryophyte community assembly in boreal forests, which is critical in

121 understanding the role of bryophytes in boreal forests in the context of global change.

\section{Methods}

123 Study area

124 Bordered to the north by the Brooks Range $\left(\sim 67^{\circ} \mathrm{N}\right)$ and to the south by the Alaska Range

$125\left(\sim 63^{\circ} \mathrm{N}\right)$, interior Alaska is characterized by isolated mountain ranges, gently sloping uplands,

126 flat lowlands and large floodplains around the Yukon, Tanana, and Kuskokwim rivers. Interior

127 Alaska has an extreme temperature range, with temperatures ranging between $-70^{\circ} \mathrm{C}$ and $35^{\circ} \mathrm{C}$, a 
128 mean annual air temperature of $-2.5^{\circ} \mathrm{C}$, and a growing season that lasts about 135 days.

129 Approximately $35 \%$ of the annual $286 \mathrm{~mm}$ of precipitation falls as snow (Hinzman et al. 2005).

130 Interior Alaska is within the discontinuous permafrost zone, and about $75-80 \%$ of the ground is

131 underlaid by permafrost (Osterkamp and Romanovsky 1999).

132 Forests in the uplands of interior Alaska are typically dominated by one of three tree

133 species: black spruce, trembling aspen, and Alaska paper birch. Black spruce stands are the most

134 common forest type in interior Alaska, accounting for an estimated 39\% of the forested

135 landscape (Calef et al. 2005), and are mostly found on wet and cold north-facing slopes with

136 permafrost (Van Cleve et al. 1983a, Yarie and Billings 2002). In black spruce stands, the forest

137 floor is usually covered by extensive bryophyte carpets composed of pleurocarpous (feather)

138 mosses such as Hylocomium splendens (Hewd) Schimp., Pleurozium schreberi (Brid.) Mitt., and

139 Ptilium crista-castrensis (Hewd.) De Not, or by Sphagnum spp. (Van Cleve et al. 1983a).

140 Deciduous-dominated stands are estimated to occupy about $24 \%$ of interior Alaska, while the

141 remainder of the landscape is principally tundra (27\%) or forested by white spruce (Picea glauca

142 (Moench) Voss; 10\%) (Calef et al. 2005). Aspen stands occupy well-drained south-facing slopes

143 with deep active layers, while birch stands, also found in deep active layer sites, are more

144 common on colder and wetter east- and west-facing slopes (Chapin et al. 2006b). Only about 6\%

145 of interior Alaska's boreal forest is composed of mixed stands with both coniferous and

146 deciduous species sharing canopy dominance (Yarie and Billings 2002). While these different

147 forest types vary in their preferred habitat, there is a considerable amount of overlap in their

148 ecological tolerances (Chapin et al. 2006b), allowing for changes canopy composition triggered

149 by disturbance, such as fire, or dispersal events (Johnstone et al. 2010a, Johnstone et al. 2010b). 
Differences in fire severity in black spruce stands can lead to the establishment of black

151 spruce, trembling aspen, or Alaska paper birch post-fire stands (Johnstone et al. 2010a,

152 Johnstone et al. 2010b), thus creating three distinct successional pathways based on canopy

153 dominance. In the boreal forests of western North American, most seedlings establish within a

154 few years after fire and they are strong predictors of the mature canopy composition of the forest

155 (Johnstone et al. 2004), thus canopy dominance appears to be principally determined by initial

156 patterns of direct regeneration (e.g. Ilison and Chen 2009). Moreover, with a fire interval of

157 about 100 years, succession from a deciduous stand to a coniferous stand via relay dominance is

158 rarely completed (Yarie 1981). We checked our assumption of direct regeneration vs. relay

159 dominance by surveying woody debris in all stands and found no evidence of deciduous trees

160 being replaced by later establishment of conifers. We therefore assume that stand age and forest

161 composition do not co-vary within the range of ages that we surveyed.

162 We used a chronosequence, or space-for-time substitution approach to examine post-fire

163 bryophyte succession. This type of study assumes that climate, regional pool of organisms,

164 topography, and parent material are held constant across sites, and only time after disturbance

165 varies (Walker et al. 2010). All the stands sampled here had originated from a fire in stands that

166 formerly contained at least some black spruce, confirmed by evidence of dead and charred black

167 spruce trees (Alexander et al. 2012). At the time of sampling, these stands were dominated by

168 either black spruce, Alaska paper birch, or trembling aspen. In order to limit other confounding

169 factors, we focused our sampling on north-, east-, and west-facing (or relatively flat) mesic black

170 spruce, Alaska paper birch, and aspen stands, and measured a number of environmental

171 covariates, including a soil description. Southeast facing slopes and poorly-drained black spruce 
172 stands were avoided as they are usually not dominated by black spruce or have a longer fire

173 cycle, respectively.

174 Sampling design

175 We surveyed a total of 83 stands ranging in age from 8-163 years in upland boreal forests

176 in interior Alaska between 2008 and 2015. The stands were stratified by time since fire and

177 forest type; stands burned within the fire history record ( $>1945)$ were located within 32 different

178 areas burned by a single fire event and mature forests were sampled in surrounding areas that had

179 not burned since 1945 (Table 1, Supplementary material 1). Burned areas were mapped by the

180 Alaska Fire Service, and their locations acquired from the Alaska Geospatial Data Clearinghouse

181 (U.S. Department of the Interior Bureau of Land Management 2012). Where possible we

182 selected at least one pure black spruce and one pure deciduous stand in each burned area

183 (Supplementary material 1). To minimize travel time between sites, all sites were located $>100$

184 and $<600 \mathrm{~m}$ from a road. We conducted extensive sampling within a successional stage for each

185 forest type to enable robust inferences from our chronosequence design (Walker et al. 2010). Our

186 study included 29 stands from early successional forests (8-19 years since fire), 45 stands in mid-

187 succession forests (20-59 years since fire, as per Alexander et al. (2012)), and 9 stands in late-

188 succession forests (60-163 years since fire). Early successional forests were sampled in 2013-14

189 using the same design as that used in the sampling of mid- to late-successional forests in 2008-

1902009 (Alexander et al. 2012).

191 Environmental variables and bryophyte identification

192 In each stand, we positioned a 100-m long transect perpendicular to the slope or used a

193 random compass bearing if the ground was flat. The methods used to measure stand structure are

194 presented in more detail in Alexander et al. (2012). Basal diameter (BD) and diameter at breast 
195 height $(\mathrm{DBH})$ of all living and dead trees and large shrubs were recorded within $1 \mathrm{~m}$ on each side

196 of the transect over a $10 \mathrm{~m}$ section for every $20 \mathrm{~m}$ subsection. In some instances, this area was

197 reduced to allow measurements of very dense early-successional stands. In stands $>20$ years old,

198 we collected a core or a basal disk from 10 trees of the dominant canopy species to confirm the

199 stand age obtained from fire history maps. Allometric equations from Alexander et al. (2012) and

200 Berner et al. (2015) were used to estimate above ground biomass of individual trees and tall

201 shrubs (Salix spp., Betula spp., and Alnus spp.). All stands were attributed to a forest type (black

202 spruce, Alaska paper birch, or aspen) based on the tree species with the largest contribution to

203 total woody biomass (Table 1, Supplementary material 1). A deciduous importance value (IV)

204 index was calculated based on the contribution of deciduous trees to total stand above-ground

205 biomass (see Alexander et al. (2012) for calculations). Organic layer thickness (fibric and humic

206 layers), mineral soil texture (only in stands sampled in 2013-2014), and pH were measured every

$20710 \mathrm{~m}$ along the transect. Soil moisture was measured using a ECH2O EC-TM soil moisture probe

208 read by an Em50 data logger (Decagon Devices Inc., Pullman, WA, U.S.A.) next to the soil

209 sampling core in all the stands sampled by Alexander et al. (2012). Soil moisture was not

210 measured in the early-successional stands in 2013 and 2014, but a general drainage class was

211 recorded for each stand (Johnstone et al. 2008). A drainage class was estimated for older stands

212 using topography and soil moisture data. Finally, we recorded slope, aspect, and GPS

213 coordinates of each transect, and calculated a heatload index (McCune and Keon 2002).

214 We used a $50 \times 50$-cm grid with 25 equally spaced sampling points to survey the

215 understory plant species composition by point-intercept sampling. All vascular and non-vascular

216 species, as well as bare ground and dead organic material (wood and leaf litter) that touched a

217 pin inserted at each sampling point were recorded. The grid was placed perpendicular to, and $1 \mathrm{~m}$ 
218 from, the transect every $20 \mathrm{~m}$ (five replicates). Cover (\%) of bare ground, coarse woody debris,

219 leaf litter, total vascular plants, and lichen were calculated and used as environmental covariates.

220 We did not sample bryophytes that grew on live or dead wood and focused instead on the

221 dominant forest floor taxa. The point-intercept sampling method presents accurate estimation of

222 the abundance of common species, but may not allow for the recording of uncommon or rare

223 species (Mamet et al. 2016, Vanderpoorten et al. 2010). Given that our main interest was linked

224 to understanding how bryophytes affect ecosystems processes, the most important information

225 from community composition would come from common species and we felt confident that

226 missing rare bryophyte species was not a problem in that regard. Samples of all encountered

227 unknown species were collected for identification in the lab. Bryophyte nomenclature followed

228 Anderson et al. (1990). We identified a total of 106 species in our samples: 67 vascular plants, 10

229 lichens, and 29 bryophytes (Table 2). Within the bryophytes, we recorded taxa from 10 families

230 of true mosses, 3 families of liverworts and one Sphagnum family. We could identify 20 true

231 mosses to the species level and 6 could only be identified to the genus level. Some unknown

232 bryophytes could not be identified because of the small size or poor quality of the samples.

233 Because of the limited taxonomic resolution, we use the term bryophyte taxa here rather than

234 species. Bryophyte taxa were further classified in functional groups of colonizers, pleurocarpous

235 mosses (feather mosses), acrocarpous mosses, liverworts and Sphagnum spp. (Table 2).

236 Bryophyte cover was summarized in three forms: total bryophyte cover, cover by functional

237 types, and cover of individual taxa. We resampled understory taxa composition in five stands of

238 varied canopy dominance surveyed by Alexander et al. (2012) in 2015 to make sure that there

239 was no significant observer bias in taxa identification and detection. 
241 All of our analyses were conducted in R 3.1.2 (R Development Core Team 2016) using the

242 package vegan (Oksanen et al. 2016). We were interested in testing whether patterns of

243 bryophyte succession in different forest successional trajectories were similar when considering

244 i) total bryophyte cover, ii) functional group cover, and iii) taxa composition. Using different

245 levels of precision allowed us to make stronger inferences about the successional patterns 246 observed (Walker et al. 2010). We did not include burn area or spatial region as a random effect

247 in our analyses because spatial arrangement was partially confounded with age (sampling within

248 discrete burned areas) and we expected age effects to supersede spatial effects on bryophyte

249 communities. Patterns of total bryophyte, functional group, and individual taxa cover were

250 compared among forest types (black spruce, birch, and aspen) and successional stages (early, 251 mid-, and late succession).

252 Total bryophyte cover, as well as the three main functional types (colonizers,

253 pleurocarpous mosses, and acrocarpous mosses) were analyzed using a two-way ANOVA (stand 254 type and successional stage) with a type III sum of squares for unbalanced data and followed by 255 a Tukey HSD post-hoc test. We assessed differences in bryophyte cover among the three canopy 256 types within each successional stage based on whether $95 \%$ confidence intervals were 257 overlapping. Data for functional groups and taxa cover did not meet ANOVA assumptions 258 because of the large number of zero values, so permutation ANOVAs were used (4999 259 permutations, Anderson and Legendre 1999).

260 We used a PerMANOVA (multivariate analysis of variance by permutations using a 261 distance-based RDA) adapted for an unbalanced design with 4999 permutations to compare taxa 262 assemblages among forest types and successional stages to patterns observed under random 
263 sorting (Anderson and Legendre 1999). The Bray-Curtis distance was used on taxa composition

264 data as it is an ecologically appropriate distance measure (Anderson and Legendre 1999).

265 Multivariate dispersion differed between the different successional stages, but not among forest

266 types. This is a well-recognized issue with multivariate analyses which can lead to a confusion

267 between within-group variation (dispersion) and mean values of the groups. PerMANOVA is

268 thought to be less sensitive to this issue than some of its alternatives (ANOSIM or MRPP)

269 (Anderson 2001). When a significant interaction was found, we conducted a series of one way

270 PerMANOVAs within each age category, followed by a Tukey HSD post hoc test.

271 To support the PerMANOVAs conducted on taxa composition data, we conducted a visual

272 analysis of taxa composition using a nonmetric multi-dimensional scaling (NMDS) ordination

273 that was conducted on taxa data from the 83 stands using the Bray-Curtis distance (McCune et

274 al. 2002). The best solution was selected from 20 independent runs with 200 iterations per run.

275 The number of ordination axes was determined by comparing stress and dimensionality against

276 randomized outcomes (McCune et al. 2002). This analysis was used to detect the main patterns

277 in taxa composition among different forest types and different successional stages.

278 Analyses of environmental covariates

279 We used two different approaches to investigate how patterns of bryophyte cover were

280 related to measured environmental covariates: univariate and multivariate regression trees, and

281 vector overlay on the NMDS ordination. Analyses were conducted in R (R Development Core

282 Team 2016) using the packages vegan (Oksanen et al. 2016) and mvpart (Therneau and Atkinson

283 2013). Ecologically relevant environmental variables (cover of bare ground cover, coarse woody

284 debris, leaf litter, vascular plant, and lichen, deciduous IV, basal area of black spruce, birch, 
285 aspen and large shrubs, elevation, heatload index, and moisture class) were selected to minimize 286 collinearity.

287 Univariate and multivariate regression (MRT) trees were the main tools used to investigate 288 the relationship between bryophyte cover or composition and environmental covariates.

289 Regression trees are non-parametric methods that are robust to issues associated with ecological 290 data such as non-normality and heteroscedasticity and make no assumptions with regards to the 291 form of the relationship between response variables and explanatory covariates (De'ath and 292 Fabricius 2000). MRTs partition the dataset recursively into subsets in order to minimize within293 group heterogeneity, providing a clustering-like result and a dichotomous classification key 294 (McCune et al. 2002). Multivariate responses of functional groups (six groups) and taxa cover 295 (25 taxa) were transformed using the Bray-Curtis distance (83 stands) prior to analysis. No 296 transformations were applied to environmental covariates. We excluded stand age and categories 297 of forest type from these analyses to focus on how changes over time in environmental 298 covariates and continuous variables of forest composition were related to bryophytes. This 299 approach allowed us to include information about the co-occurring tree species in the stands and 300 interpret the potential effects of gradients in canopy composition rather than simple canopy 301 dominance. MRT results are described both by their fit, or percent variation explained, which is 302 calculated as the inverse of the relative error (RE), as well as their predictive accuracy estimated 303 by the cross-validated error (CVRE). This number estimates the probability of misclassifying a 304 new sample and varies from 0 (good predictor) to 1 (poor predictor) (De'ath and Fabricius 2000).

305 To compare variations in leaf litter cover according to forest types and successional stage, we 306 conducted a two way ANOVA followed by a Tukey HSD post hoc. 
We used vector overlays on the NMDS ordination to determine how all covariates were

308 related to bryophyte taxa composition. Pearson correlation coefficients between environmental

309 variables and NMDS scores defined the strength of correlations with ordination axes.

310 Significance of the correlation was determined using 999 permutations.

\section{Results}

312 Part I: Temporal changes in bryophyte communities

313 Total bryophyte cover

314 Bryophyte cover varied according to forest type and the three post-fire successional stages

315 (interaction $\mathrm{F}_{4,74}=8.524, \mathrm{p}<0.0001$; Figure 1, Table 1). Bryophyte cover was high in all early-

316 successional forest types $(\bar{x}=69 \%$, Figure 1, Table 1$)$. While total bryophyte cover was reduced

317 to an average of $40 \%$ during the mid-successional stage, it was higher in stands dominated by

318 spruce $(\bar{x}=53 \%)$ compared to birch or aspen $(\bar{x}=34 \%$ and $\bar{x}=23 \%$, respectively; Table 1$)$.

319 Bryophyte cover increased in late succession to an average of $88 \%$ in spruce stands, much higher 320 than the cover observed in aspen $(\bar{x}=32 \%)$ or birch $(\bar{x}=9 \%)$ during late succession (Figure 1,

321 Table 1). However, it is important to note the time series for birch was not as long as for the 322 other tree species. Differences in total bryophyte cover among forest types indicate a divergence 323 in bryophyte cover between coniferous (spruce) and deciduous (birch and aspen) forest types 324 between 20 and 40 years after fire (Figure 1).

$325 \quad$ Functional groups

326 Colonizer taxa declined quickly from 8 to 40 years, demonstrating a strong effect of 327 successional stage $\left(\mathrm{F}_{2,74}=91.435, \mathrm{p}=0.0002\right.$; Supplementary material $\left.3 \mathrm{a}\right)$, and followed very 328 similar trends in all forest types (Table 3, Figure 2). Bryophyte communities in all forest types 329 were dominated by Ceratodon purpureus and Marchantia polymorpha from 10-20 years after 
330 fire, and were then dominated by larger acrocarpous taxa such as Polytrichum commune and

331 Polytrichum juniperinum from 20-40 years after fire (Table 2). Pleurocarpous mosses remained

332 low in deciduous stands throughout succession, but they increased in spruce stands to an average

333 of $63 \%$ cover in late succession $\left(\mathrm{F}_{4,74}=10.111, \mathrm{p}<0.0001\right.$; Table 3, Figure 2, and Supplementary

334 material 3b). Pleurocarpous mosses represented about two thirds of the total bryophyte cover in

335 mature spruce stands. The feather mosses Pleurozium schreberi and Hylocomium splendens

336 shared the dominance of the pleurocarpous moss cover in all stands (Table 2). P. schreberi

337 seemed to be slightly more abundant than $H$. splendens until about 100 years since fire in spruce

338 stands (Table 2). The cover of acrocarpous mosses (e.g. Aulacomnium spp., Dicranum spp.) was

339 higher in spruce stands (about 18\%) than in deciduous stands $(<7 \%)\left(\mathrm{F}_{2,74}=10.460, \mathrm{p}=0.0014\right.$;

340 Supplementary material 3c), and remained relatively low in all forest types regardless of stand

341 age (Table 3, Figure 2b). Sphagnum spp. cover increased steadily in older spruce stands and was

342 absent from deciduous stands, while liverworts were rare in all forest types at every stage of

343 succession (Table 3).

344 Taxa composition

345 Ordination of the bryophyte taxa for all forest types and all ages resulted in a two-

346 dimensional NMDS solution that captured $38 \%$ of the variation in the original ranked distance

347 matrix (Figure 3, stress 0.18). This level of stress indicates that the ordination is able to capture

348 meaningful patterns in the data, with small distortions in the representation (McCune et al.

349 2002). The two axes from the NMDS represent two main ecological gradients; changes

350 associated with stand age (NMDS 1) and leaf litter cover (NMDS 2, Table 4). There was a

351 significant interaction between forest type and successional stage (interaction $\mathrm{F}_{4,74}=2.19$,

$352 \mathrm{p}=0.003$, Supplementary material 2a). 
During early succession (5-19 years since fire), taxa composition did not significantly

354 differ among the three forest types $\left(\mathrm{F}_{2,26}=1.89, \mathrm{p}=0.057\right.$; Supplementary material $\left.2 \mathrm{~b}\right)$. Stands of

355 different types occupied a similar area of the multivariate space in the NMDS ordination (Figure

356 3a). Composition of non-vascular understory taxa in in all forest types was dominated by

357 colonizers, such as M. polymorpha, P. juniperinum, C. purpureus, and taxa of the Bryaceae

358 family (includes taxa such as Leptobryum pyriforme, Bryum spp., and Pohlia spp.) (Figure 3a).

359 During mid-succession (20-60 years since fire), taxa composition started to diverge among

360 forest types $\left(\mathrm{F}_{2,39}=2.848, \mathrm{p}>0.001\right.$; Supplementary material $\left.2 \mathrm{c}\right)$. Bryophyte communities in birch

361 and aspen stands only partly overlapped the multivariate space occupied by communities in

362 coniferous spruce stands (Figure 3b). Taxa composition in spruce stands differed from that of

363 aspen stands, but was similar to that of birch stands, and there was no difference in taxa

364 composition among the two deciduous forest types ( $p$ values in Supplementary material 4c). Rare

365 taxa from the Hypnales order, such as Amblystegium spp., Drepanocladus spp., Brachythecium

366 spp, and Ptilium crista-castrensis, dominated the bryophyte layer in deciduous stands (Figure

367 3b). In spruce stands, feather mosses (P. schreberi, H. splendens) became dominant, along with

368 Dicranum spp. and Aulacomnium palustre. Taxa composition in the earliest years of the mid-

369 succession stage overlapped among all forest types.

370 Bryophyte communities in late-succession ( $\geq 60$ years since fire) were significantly

371 different in taxa composition among forest types $\left(\mathrm{F}_{2,9}=4.429, \mathrm{p}>0.001\right.$; Supplementary material

372 2d). Some bryophyte taxa found in older stands could not be identified, often because the

373 specimens were too small to lead to a conclusive identification, but likely comprised

374 Brachythecium spp. and Hypnum spp., among others. Bryophyte taxa composition of aspen and

375 birch stands was similar ( $\mathrm{p}=0.417$; Supplementary material $4 \mathrm{~d})$, but differed from spruce stands 
$376(p=0.048$ and $p=0.001$, respectively; Supplementary material $2 d)$. In spruce stands, the feather

377 mosses H. splendens and P. schreberi remained dominant components of the bryophyte carpet,

378 and Sphagnum spp. cover increased.

379 Part II: Environmental covariates related to bryophyte divergence

380 Total bryophyte cover

381 In the regression tree analysis, leaf litter was the best predictor of total bryophyte cover,

382 with $76 \%$ cover identified as a threshold value (Figure 4). This threshold value was reached at

383 about 20 years in aspen stands, 40 years in birch stands, and only a few very young spruce stands

384 presented such a high leaf litter cover, probably derived from the high cover of deciduous shrubs

385 in those stands. When leaf litter cover was high, stands with more than $4 \%$ cover of bare ground

386 had higher bryophyte cover (younger stands), while stands having less than 4\% bare ground

387 cover had lower bryophyte cover and corresponded to older stands (Figure 4). When leaf litter

388 cover was low, depth of the organic layer was the next important variable associated with total

389 bryophyte cover (Figure 4). Stands with an organic layer $<8 \mathrm{~cm}$ deep had a lower bryophyte

390 cover, were slightly younger, and canopy composition was split evenly between spruce and

391 deciduous stands. Stands with a deeper organic layer were mostly spruce stands and had the

392 highest bryophyte cover of all groups (72\%, Figure 4).

393 Leaf litter cover varied according to forest type and post-fire successional stage

$394\left(\mathrm{~F}_{4,74}=6.938, \mathrm{p}<0.0001\right.$, Figure 5). During early succession, leaf litter cover was similar among

395 forest types $(\bar{x}=69 \%)$. Differences in leaf litter cover occurred during mid-succession when

396 litter cover decreased to $50 \%$ in spruce stands and increased to about $76 \%$ (threshold identified

397 by the regression tree) in both deciduous forest types. The difference in litter cover among stand

398 types increased during the late successional stage with litter cover reduced to a mean of $33 \%$ in 
399 spruce stands, and increased to $94 \%$ in birch and aspen stands. The divergence in leaf litter

400 cover among the forest types occurred at 20-40 years after fire.

401 Functional groups and taxa composition

402 Multivariate regression trees predicting functional group cover or bryophyte taxa

403 composition were very similar (Figure 6). In both cases, bare ground was the most prominent

404 covariate associated with bryophyte communities, as it captured a threshold between younger

405 (high bare ground cover) and older (low bare ground cover) stands. Leaf litter cover was the next

406 most important variable, with thresholds of $78.8 \%$ for functional groups and $76.8 \%$ for taxa

407 composition (Figure 6). A lower leaf litter cover was associated with either younger stands or

408 mature spruce stands for functional groups (Figure 6a), or with mature spruce stands for the taxa

409 composition data (Figure 6b). In both regression trees, stands with a high leaf litter cover were

410 associated with distinct bryophyte communities mostly in mature deciduous stands (Figure 6).

411 Results from the environmental vector fitting on the NMDS indicated that bare ground

412 cover and age, which were inversely correlated to each other, were the main variables associated

413 with the distribution of the stands along Axis 1 in the multidimensional space of the ordination

414 (Table 4). Leaf litter cover was the main variable associated to the distribution of stands along

415 Axis 2 (Figure 3d, Table 4). Spruce stands in mid- and late succession were associated with a

416 thick organic layer, higher spruce basal area, and higher soil moisture. Birch and aspen stands in

417 mid- and late succession were associated with higher basal areas of birch and aspen, and higher

418 leaf litter cover (Figure 3d, Table 4). We found a significant interaction of forest type and

419 successional stage $\left(\mathrm{F}_{4,74}=2.194, \mathrm{p}=0.0030\right.$; Supplementary material $\left.4 \mathrm{a}\right)$ in explaining taxa

420 composition, which supported the visual interpretation of the NMDS plot in Figure 3a-c. 


\section{Discussion}

422 We identified a clear time scale of changes in bryophyte abundance and taxa composition 423 driven by canopy composition in boreal forests of interior Alaska. Our results are based on a 424 unique empirical dataset documenting patterns of bryophyte cover and community composition 425 across an 8-163 year chronosequence of contrasting boreal forest canopy types. To our 426 knowledge, few studies have focused on boreal understory communities in different forest types

427 of similar ages (Hart and Chen 2006) or included different successional stages in such a 428 comparison. Our findings support the interpretation of bryophyte communities diverging in 429 response to changing canopy composition (De Grandpré et al. 1993, Hart and Chen 2006). 430 Bryophyte cover and community composition were similar among forest types in early 431 succession, but then diverged between coniferous (black spruce) and deciduous (Alaska paper 432 birch and trembling aspen) forest types between 20 and 40 years after fire. These changes in the 433 bryophyte understory appear to be driven by differences in litter cover caused by higher annual 434 production of litter in deciduous stands (Melvin et al. 2015), consistent with the hypothesis that 435 chemical and physical aspects of leaf litter affect the growth and survival of understory taxa 436 (Barbier et al. 2008). A threshold of about 75\% leaf litter cover was associated with a large 437 reduction in bryophyte cover and a change in taxa composition among the 83 stands in our study. 438 Our results identify unique successional patterns strongly related to canopy types and highlight 439 the important role of leaf litter in regulating bryophyte communities.

440 Bryophyte communities in post-fire aspen, birch and spruce forests were similar in the 441 early successional stages during the first 6-20 years after fire. Thus, we must reject the 442 hypothesis that differences in bryophyte composition among mature coniferous vs. deciduous 443 stands are attributable to distinct successional trajectories that arise immediately after fire. 
444 Instead, our data suggest bryophyte communities in early succession are strongly influenced by

445 common dynamics of colonization that are similar regardless of the composition of the young

446 forest canopy. Young stands of all forest types had a high bryophyte cover $(\sim 75 \%)$ dominated by

447 colonizing and pyrophilic taxa such as Ceratodon purpureus, Leptobryum pyriforme, Marchantia 448 polymorpha, and Polytrichum spp. (Hart and Chen 2006, Turetsky et al. 2010). Early

449 successional stands had more exposed bare ground than older stands, which is representative of 450 the time necessary to recruit bryophytes from diaspores. The youngest stands were dominated by 451 C. purpureus (6-20 years), a pioneer taxa intolerant of competition, which was likely overgrown 452 by the larger and more competitive $P$. juniperinum and $P$. commune that dominated stands 20-40 453 years after fire (Gloaguen 1990). Extensive carpets of Polytrichum spp. are common following 454 disturbances in multiple ecosystems (Foster 1985, Gloaguen 1990).

455 The similarity among bryophyte communities we observed in early succession contrasts

456 with existing research showing impacts of fire severity on bryophyte abundance and richness two 457 years after fire (Bernhardt et al. 2011, Hollingsworth et al. 2013). We hypothesize that the short 458 term responses of bryophyte communities to fire severity are likely masked within a few years 459 by the opposing impacts of fire severity on survival versus colonisation. Immediately after fire, 460 incomplete combustion of the organic layer in low severity fires promotes bryophyte abundance 461 because of remnant live bryophytes and fragments (Thomas et al. 1994, Bernhardt et al. 2011, 462 Fenton and Bergeron 2013). However, high severity fires provide seedbeds of mineral soil and 463 ashes that are good substrates for subsequent bryophyte colonization (Thomas et al. 1994, 464 Bernhardt et al. 2011, Fenton and Bergeron 2013). Thus, bryophyte regeneration after fire is 465 supported by opposite mechanisms of recruitment depending on the fire behaviour and leads to a 466 similar trajectory of bryophyte development in early successional stands. 
At the transition between early and mid-successional stages, the cover of colonizing taxa

468 declined abruptly and at a similar pace in all forest types. We suspect that different processes led

469 to the change in bryophyte communities in coniferous versus deciduous forest types. In spruce

470 stands, the decrease in abundance of colonizers between 20 and 40 years since fire is

471 synchronous with an increase in abundance of pleurocarpous feather mosses, suggesting that

472 competition between colonizing taxa and feather mosses may be an important process (autogenic

473 succession) (Rydin 1997). In deciduous stands, this decline in colonizers corresponded to a

474 significant increase in leaf litter cover, meaning that in deciduous stands, external factors such as

475 leaf litter and canopy closure may be more important (allogenic succession). More detailed

476 studies, for example manipulative experiments with reciprocal bryophyte transplants, would help

477 to clarify the role of competition and environmental variables in bryophyte succession.

By 40 years after fire, bryophyte cover and community composition differed among forest

479 cover types, indicating a divergence in successional pathways related to canopy cover in mid-

480 succession. This time period corresponds with the timing of canopy closure in spruce-dominated

481 stands (Chapin et al. 2006a), which comes with a decrease in light availability and, as we

482 observed, a decrease in deciduous tree and shrub litter in spruce stands (Turetsky et al. 2010).

483 Bryophyte cover was high in mid- and late succession spruce stands (close to $100 \%$ in older

484 stands) and was dominated by the feather mosses Pleurozium schreberi and Hylocomium

485 splendens. P. schreberi remained the dominant taxa throughout most of this period, always

486 covering between 5 and $15 \%$ more than $H$. splendens until about 100 years after fire. In some of

487 our oldest black spruce stands, Sphagnum spp. was present. The few stands older than 90 years

488 limit the conclusions we can draw for this successional stage. The patterns we observed are

489 consistent with other studies of black spruce forests that document establishment of Sphagnum 
490 after about 100 years post-fire, following changes in soil temperature and moisture initiated by

491 extensive development of feather mosses (Fenton and Bergeron 2006, Turetsky et al. 2010).

492 Bryophyte succession in spruce stands seems to be triggered first by the decrease in deciduous

493 leaf litter associated with spruce canopy closure, and afterwards is driven by autogenic processes

494 influenced by feather mosses.

495 Canopy composition and associated variations in leaf litter production are recognized as

496 major factors influencing understory communities in boreal forests (De Grandpré et al. 1993,

497 Hart and Chen 2006). Broadleaf litter may form a physical barrier to bryophyte growth (Van

498 Cleve et al. 1983b, Startsev et al. 2008), increase nutrient availability in ways that reduce the

499 competitive ability of bryophytes, and may have allelopathic effects (Startsev et al. 2008). Strong

500 (2011) found a decline in the abundance of Hylocomium splendens in northwestern Canada in

501 stands with aspen canopy cover over $40 \%$, consistent with our observations of a significant

502 decline in bryophyte abundance above a threshold of $75 \%$ leaf litter cover, or roughly $50 \%$

503 deciduous canopy cover (estimated from basal area). Bryophytes in deciduous stands were rare

504 throughout mid- and late succession and often restricted to decomposing logs or mounds where

505 leaf litter was blown away. Increases in canopy gaps and decomposing logs that shed leaf litter

506 with aging deciduous stands may allow feather mosses to increase in abundance late in

507 succession (Jonsson and Esseen 1990). This pattern was reported for aspen stands $>75$ years old

508 by Strong (2009), and was apparent in one of our old aspen stands (Figure 1); however, our

509 inference is constrained by a low sample size of deciduous-dominated forest stands older than

510100 years. Nevertheless the change in bryophyte communities in deciduous stands seems to be

511 mostly driven by allogenic factors linked to canopy development. 
512 The dominance of pleurocarpous feather mosses in spruce stands (Turetsky et al. 2012) and

513 their low abundance in aspen and birch stands is critical from an ecosystem functioning

514 perspective. Feather mosses are long-lived perennials, relatively large and fast growing, and are

515 good competitors that can quickly take advantage of newly opened substrates by shoot

516 encroachment (Frego 1996). Feather mosses build organic layers that enhance soil insulation and

517 maintain shallow active layers (Turetsky et al. 2012), as well as retain soil moisture (Turetsky et

518 al. 2010). We found a positive association between bryophyte abundance and organic layer

519 depth, which can be linked to reestablishment of permafrost 20-30 years after fire (Viereck et al.

520 2008). Associations between feather mosses and cyanobacteria are also involved in biological

521 nitrogen (N) fixation (DeLuca et al. 2002). If deciduous seedlings take advantage of exposed

522 mineral soil following severe fires and replace black spruce as the dominant forest canopy

523 (Johnstone et al. 2004, Johnstone et al. 2010b), increased production of leaf litter may prevent

524 the subsequent recovery of feather mosses during succession. Low bryophyte cover in deciduous

525 stands in mid-succession promotes the stability of this alternate forest type by supporting warm

526 and dry soil conditions with high nutrient availability (Johnstone et al. 2010a). Colonizing

527 bryophyte taxa such as Polytrichum spp. do not have the same impacts on the ecosystem in terms

528 of insulation (Soudzilovskaia et al. 2011), water retention (Elumeeva et al. 2011), and hosting N-

529 fixers (Gavazov et al. 2010).

530 Divergence of bryophyte communities among canopy types at about 40 years after fire, i.e.

531 during mid-succession, indicated that divergence in succession is arising due to increasing

532 canopy effects as stands mature, rather than differences being caused by direct initial effects of

533 fire severity. Black spruce forests are the most widespread forest type in interior Alaska (Calef et

534 al. 2005), and bryophyte functional traits promote the resilience of black spruce forests through 
535 their effects on soil moisture, soil temperature, nutrient cycling, and flammability, among others

536 (Johnstone et al. 2010a, Turetsky et al. 2012). Feedbacks between canopy, leaf litter production,

537 and understory bryophytes throughout post-fire forest regeneration are keys to our understanding

538 of ecosystem resilience in interior Alaska in a context of climate change (Johnstone et al. 2010a).

539 Changes in canopy dominance towards more mixed and deciduous stands will therefore have

540 major impacts on boreal ecosystem functioning through the negative impacts of deciduous trees

541 and leaf litter on feather mosses.

\section{Conclusion}

Bryophyte communities in interior Alaska followed divergent successional trajectories

544 associated with vascular canopy cover (deciduous vs. coniferous) despite similar patterns during

545 the first 40 years after fire. Autogenic processes such as competition within the bryophyte layer

546 in spruce stands, and allogenic processes such as changes in leaf litter cover in deciduous stands

547 were associated with divergence in bryophyte communities among forest types, with a transition

548 to feather moss in spruce stands and low bryophyte abundance in birch and aspen stands. Black

549 spruce stands in mid- and late succession are characterized by an understory of feather mosses

550 and Sphagnum spp. with thick organic layers, conditions that support further dominance of black

551 spruce. However, in deciduous stands, reduction in bryophyte cover at a threshold of $\sim 75 \%$ leaf

552 litter cover supports conditions favorable to maintenance of deciduous dominance, such as warm

553 soils and high nutrient availability. Feather mosses also affect important ecosystem processes in

554 boreal ecosystems, such as carbon storage, soil microclimate regulation, and nitrogen fixation.

555 Changes in fire regime that lead to an increase in deciduousness in interior Alaska (Mann et al.

556 2012) will likely also alter bryophyte communities and have cascading impacts on boreal

557 ecosystem functioning. Temporal changes in bryophyte communities induced by leaf litter cover 
558 is a key aspect to our understanding of the processes that stabilize compositional patterns of

559 boreal forests, and is critical for predicting ecosystem responses to environmental change.

$560 \quad$ Acknowledgements

561 We would like to thank Alix Conway, Xanthe Walker, Nicolas Boldt, Patricia Tomchuk, 562 and Dominic Olver from the University of Saskatchewan, as well as Kamala Earl, Camilo

563 Mojica, Nils Pederson, Leslie Boby, Mindy Sun, and Jennifer Stanley from the University of

564 Florida for their help in the field and laboratory, and Dr. Terry McIntosh for his support in in

565 verification of the 2013-2015 bryophyte specimens. We appreciate the assistance of the US

566 Army for allowing access to burned areas on military lands. Funding for this research was

567 provided by the Department of Defense's Strategic Environmental Research and Development

568 Program (SERDP) under project RC-2109, the Natural Science and Engineering Research

569 Council of Canada (NSERC), and the Northern Scientific Training Program (NSTP), as well

570 as NASA Ecosystems and Carbon Cycle Grant NNX08AG13G and the Bonanza Creek Long

571 Term Ecological Research Site program funded by NSF DEB-0620579 and USDA Forest

572 Service, Pacific Northwest Research Station, grant PNW01-JV11261952-23.

573

574 
575

576

577

578

579

580

581

582

583

584

585

586

587

588

589

590

591

592

593

594

595

596

597

\section{References}

Alexander H.D., Mack M.C., Goetz S., Beck P.S.A., and Belshe E.F. 2012. Implications of increased deciduous cover on stand structure and aboveground carbon pools of Alaskan boreal forests. Ecosphere 3:45.

Anderson, L.E., Crum, H.A. \& Buck, W.R. 1990. List of mosses of North America north of Mexico. The Bryologist 93:448-499.

Anderson M.J. 2001. A new method for non-parametric multivariate analysis of variance. Austral Ecol. 26:32-46.

Anderson M.J., Legendre P. 1999. An empirical comparison of permutation methods for tests of partial regression coefficients in a linear model. J. Stat. Comput. Simul. 62:271-303.

Barbier S., Gosselin F., and Balandier P. 2008. Influence of tree species on understory vegetation diversity and mechanisms involved - A critical review for temperate and boreal forests. For. Ecol. Manage. 254:1-15.

Berner L.T., Alexander H.D., Loranty M.M., Ganzlin P., Mack M.C., Davydov S.P., and Goetz S.J. 2015. Biomass allometry for alder, dwarf birch, and willow in boreal forest and tundra ecosystems of far northeastern Siberia and north-central Alaska. For. Ecol. Manage. 337:110-118.

Bernhardt E.L., Hollingsworth T.N., and Chapin F.S. III. 2011. Fire severity mediates climatedriven shifts in understorey community composition of black spruce stands of interior Alaska. J. Veg. Sci. 22:32-44.

Calef M.P., David McGuire A., Epstein H.E., Rupp T.S., and Shugart H.H. 2005. Analysis of vegetation distribution in interior Alaska and sensitivity to climate change using a logistic regression approach. J. Biogeogr. 32:863-878. 
598 Chapin F.S. III, Viereck L.A., Adams P.C., Van Cleve K., Fastie C.L., Ott R.A., Mann D.H., and Johnstone J.F. 2006a. Successional processes in the Alaskan boreal forest. Chapin F.S. III, Oswood MW, Van Cleve K, Viereck LA, Verbyla DL, editors. Alaska's Changing Boreal Forest. Oxford Univeristy Press, New York. p100-120.

Chapin F.S. III, Hollingsworth T., Murray D.F., Viereck L.A., and Walker M.D. 2006b. Floristic diversity and vegetation distribution in the Alaskan boreal forest. Chapin F.S. III, Oswood MW, Van Cleve K, Viereck LA, Verbyla DL, editors. Alaska's Changing Boreal Forest. Oxford University Press, New York. p81-99.

De'ath G. , Fabricius K.E. 2000. Classification and regression trees: a powerful yet simple technique for ecological data analysis. Ecology 81:3178-3192.

De Grandpré L., Gagnon D., and Bergeron Y. 1993. Changes in the understory of Canadian southern boreal forest after fire. J. Veg. Sci. 4:803-810.

DeLuca T.H., Zackrisson O., Nilsson M.C., and Sellstedt A. 2002. Quantifying nitrogen-fixation in feather moss carpets of boreal forests. Nature 419:917-920.

612 Elumeeva T.G., Soudzilovskaia N.A., During H.J., and Cornelissen J.H.C. 2011. The importance of colony structure versus shoot morphology for the water balance of 22 subarctic bryophyte species. J. Veg. Sci. 22:152-164.

Fenton N.J., Bergeron Y. 2013. Stochastic processes dominate during boreal bryophyte community assembly. Ecology 94:1993-2006. by changes in available moisture and light. J. Veg. Sci. 17:65-76. 
621 Frego K.A. 1996. Regeneration of four boreal bryophytes: colonization of experimental gaps by naturally occurring propagules. Can. J. Bot. 74:1937-1942.

623 Gavazov K.S., Soudzilovskaia N.A., Logtestijn R.S.P., Braster M., and Cornelissen J.H.C. 2010. Isotopic analysis of cyanobacterial nitrogen fixation associated with subarctic lichen and

Gloaguen J.C. 1990. Post-burn succession on Brittany heathlands. J. Veg. Sci. 1:147-152.

\section{7}

Hart S.A., Chen H.Y.H. 2006. Understory vegetation dynamics of North American boreal forests. Crit. Rev. Plant Sci. 25:381-397.

Hinzman L.D., Bettez N.D., Bolton W.R., Chapin F.S. III, Dyurgerov M.B., Fastie C.L., Griffith B., Hollister R.D., Hope A., Huntington H.P., Jensen A.M., Jia G.J., Jorgenson T., Kane D.L., Klein D.R., Kofinas G., Lynch A.H., Lloyd A.H., McGuire A.D., Nelson F.E., Oechel W.C., Osterkamp T.E., Racine C.H., Romanovsky V.E., Stone R.S., Stow D.A., Sturm M., Tweedie C.E., Vourlitis G.L., Walker M.D., Walker D.A., Webber P.J., Welker J.M., Winker K., and Yoshikawa K. 2005. Evidence and implications of recent climate change in northern Alaska and other arctic regions. Clim. Change 72:251-298.

Hollingsworth T.N., Johnstone J.F., Bernhardt E.L., and Chapin F.S. III. 2013. Fire severity filters regeneration traits to shape community assembly in Alaska's boreal forest. PLoS ONE 8:e56033.

Ilisson, T., Chen H.Y.H. 2009. The direct regeneration hypothesis in northern forests. J. Veg. Sci. 20:735-744.

Johnstone J.F., Chapin F.S. III, Foote J., Kemmett S., Price K., and Viereck L. 2004. Decadal observations of tree regeneration following fire in boreal forests. Can. J. For. Res. 34:267-273. 
644 Johnstone J.F., Chapin F.S. III, Hollingsworth T.N., Mack M.C., Romanovsky V., and Turetsky

645 M. 2010a. Fire, climate change, and forest resilience in interior Alaska. Can. J. For. Res.

$646 \quad 40: 1302-1312$.

647 Johnstone J.F., Hollingsworth T.N., and Chapin F.S. III. 2008. A key for predicting postfire successional trajectories in black spruce stands of interior Alaska PNW-GTR-767. USDA Forest Service, Pacific Northwest Research Station, Portland, OR.

650 Johnstone J.F., Hollingsworth T.N., Chapin F.S. III, and Mack M.C. 2010b. Changes in fire regime break the legacy lock on successional trajectories in Alaskan boreal forest. Global

Jonsson B.G. , Esseen P.-A. 1990. Treefall disturbance maintains high bryophyte diversity in a 654 boreal spruce forest. J. Ecol. 78:924-936.

Mamet S.D., Young N., Chun K.P., and Johnstone J.F. 2016. What is the most efficient and effective method for long-term monitoring of alpine tundra vegetation? Arctic Science 2:127-141.

McCune B., Grace J.B., and Urban D.L. 2002. Analysis of ecological communities. Gleneden Beach (OR): MjM software design. 300 p. load. J. Veg. Sci. 13:603-606. Differences in ecosystem carbon Distribution and nutrient cycling linked to forest tree species composition in a mid-successional boreal forest. Ecosystems 18:1472-1488. 
667 Oksanen J., Blanchet F.G., Kindt R., Legendre P., Minchin P.R., O'Hara R.B., Simpson G.L., 668 Solymos P., Stevens M.H.H., and Wagner H. 2016. vegan: Community ecology package. 669 R package version 2.4-1. https://CRAN.R-project.org/package=vegan.

670 Osterkamp T.E., Romanovsky V.E. 1999. Evidence for warming and thawing of discontinuous 671 permafrost in Alaska. Permafrost Periglacial Process. 10:17-37.

672 R Development Core Team. 2016. R: A language and environment for statistical computing. R Foundation for Statistical computing, Vienna, Austria. https://www.R-project.org/.

674 Rydin H. 1997. Competition among bryophytes. Adv. Bryol. 6:135-168.

675 Soudzilovskaia N.A., Graae B.J., Douma J.C., Grau O., Milbau A., Shevtsova A., Wolters L., and Cornelissen J.H.C. 2011. How do bryophytes govern generative recruitment of vascular plants? New Phytol. 190:1019-1031.

Startsev N., Lieffers V.J., and Landhäusser S.M. 2008. Effects of leaf litter on the growth of boreal feather mosses: Implication for forest floor development. J. Veg. Sci. 19:253-260.

Strong W. 2009. Populus tremuloides Michx. postfire stand dynamics in the northern borealcordilleran ecoclimatic region of central Yukon Territory, Canada. For. Ecol. Manage.

Strong W. 2011. Tree canopy effects on understory species abundance in high-latitude Populus tremuloides stands, Yukon, Canada. Community Ecol. 12:89-98.

Therneau T.M., Atkinson B. 2013. mvpart: Multivariate partitioning. R package version 1.6-2. https://cran.r-project.org/src/contrib/Archive/mvpart/.

687 Thomas P.A., Proctor M.C.F., and Maltby E. 1994. The ecology of severe moorland fire on the North York moors: Chemical and physical constraints on moss establishment from spores. J. Ecol. 82:457-474. 
690 Turetsky M.R., Bond-Lamberty B., Euskirchen E., Talbot J., Frolking S., McGuire A.D., and

691 Tuittila E.S. 2012. The resilience and functional role of moss in boreal and arctic ecosystems. New Phytol. 196:49-67.

693 Turetsky M.R., Mack M.C., Hollingsworth T.N., and Harden J.W. 2010. The role of mosses in ecosystem succession and function in Alaska’s boreal forest. Can. J. For. Res. 40:12371264.

U.S. Department of the Interior Bureau of Land Management. 2012. Alaska geospatial data clearinghouse. http://agdc.usgs.gov/data/blm/fire.

698 Van Cleve K., Dyrness C.T., Viereck L.A., Fox J., Chapin F.S. III, and Oechel W. 1983a. Taiga ecosystems in interior Alaska. Bioscience 33:39-44.

700 Van Cleve K., Oliver L., Schlentner R., Viereck L.A., and Dyrness C.T. 1983b. Productivity and nutrient cycling in taiga forest ecosystems. Can. J. For. Res. 13:747-766.

Van Cleve K., Viereck L.A. 1981. Forest succession in relation to nutrient cycling in the boreal forest of Alaska. West DC, Shugart HH, Botkin DB, editors. Forest Succession, Concepts and Application. Springer-Verlag, New York (NY). p184-211.

Vanderpoorten A., Papp B., Gradstein R., Eyman J., Degreef J., Häuser C., Monje J.C., Samyn Y., D. Vanden Spiegel (Eds.), Sampling of bryophytes, ABC Taxa, Belgium (2010), pp. $340-354$.

708 Viereck L.A., Werdin-Pfisterer N.R., Adams P.C., and Yoshikawa K. 2008. Effect of wildfire and fireline construction on the annual depth of thaw in a black spruce permafrost forest in interior Alaska: a 36-year record of recovery. In Proceedings of the Ninth International Conference on Permafrost, Fairbanks, Alaska. p1845-1850. 
712 Walker L.R., Wardle D.A., Bardgett R.D., and Clarkson B.D. 2010. The use of chronosequences 713 in studies of ecological succession and soil development. J. Ecol. 98:725-736.

714 Yarie J. 1981. Forest fire cycles and life tables: a case study from interior Alaska. Can. J. For. $715 \quad$ Res. 11:554-562.

716 Yarie J. , Billings S. 2002. Carbon balance of the taiga forest within Alaska: present and future. 717 Can. J. For. Res. 32:757-767.

718

719 
720 Table 1: Number of sites sampled and average site characteristics (with standard errors)

721 according to estimated time since fire (years) and forest canopy type.

\begin{tabular}{|c|c|c|c|c|c|c|c|c|c|}
\hline & \multicolumn{3}{|c|}{$\begin{array}{l}\text { Early succession } \\
\text { (8-19 years) }\end{array}$} & \multicolumn{3}{|c|}{$\begin{array}{l}\text { Mid-succession } \\
\text { (20-59 years) }\end{array}$} & \multicolumn{3}{|c|}{$\begin{array}{l}\text { Late succession } \\
\text { (60-163 years) }\end{array}$} \\
\hline & $\begin{array}{l}\text { Black } \\
\text { spruce }\end{array}$ & $\begin{array}{l}\text { Alaska } \\
\text { paper } \\
\text { birch }\end{array}$ & $\begin{array}{l}\text { Trembling } \\
\text { aspen }\end{array}$ & $\begin{array}{l}\text { Black } \\
\text { spruce }\end{array}$ & $\begin{array}{l}\text { Alaska } \\
\text { paper } \\
\text { birch }\end{array}$ & $\begin{array}{c}\text { Tremblin } \\
\mathrm{g} \text { aspen }\end{array}$ & $\begin{array}{l}\text { Black } \\
\text { spruce }\end{array}$ & $\begin{array}{l}\text { Alaska } \\
\text { paper } \\
\text { birch }\end{array}$ & $\begin{array}{l}\text { Trembling } \\
\text { aspen }\end{array}$ \\
\hline Number of sites & 7 & 9 & 13 & 21 & 7 & 14 & 5 & 4 & 3 \\
\hline Bryophyte cover $(\%)^{1}$ & $\begin{array}{c}69.5 \text { be } \\
(12.2)\end{array}$ & $\begin{array}{l}71.3 \mathrm{de} \\
(16.1)\end{array}$ & $\begin{array}{c}66.3 \text { be } \\
(15.1)\end{array}$ & $\begin{array}{c}52.7 \mathrm{bcd} \\
(19.6)\end{array}$ & $\begin{array}{c}33.9 \mathrm{ac} \\
(26.3)\end{array}$ & $\begin{array}{l}23.5 \mathrm{a} \\
(15.5)\end{array}$ & $\begin{array}{l}87.7 \mathrm{e} \\
(15.3)\end{array}$ & $\begin{array}{c}8.6 \mathrm{a} \\
(10.4)\end{array}$ & $\begin{array}{c}31.7 \mathrm{ab} \\
(13.6)\end{array}$ \\
\hline Leaf litter cover $(\%)$ & $\begin{array}{l}68.3 \\
(4.2)\end{array}$ & $\begin{array}{c}62.6 \\
(11.3)\end{array}$ & $\begin{array}{l}74.8 \\
(8.5)\end{array}$ & $\begin{array}{c}50.9 \\
(17.7)\end{array}$ & $\begin{array}{c}73.6 \\
(20.3)\end{array}$ & $\begin{array}{c}75.1 \\
(19.8)\end{array}$ & $\begin{array}{c}33.8 \\
(13.2)\end{array}$ & $\begin{array}{l}94.8 \\
(2.5)\end{array}$ & $\begin{array}{l}88.0 \\
(3.7)\end{array}$ \\
\hline Organic layer $(\mathrm{cm})$ & $\begin{array}{c}9.7 \\
(3.5)\end{array}$ & $\begin{array}{c}9.9 \\
(2.0)\end{array}$ & $\begin{array}{c}7.6 \\
(3.8)\end{array}$ & $\begin{array}{l}10.1 \\
(5.1)\end{array}$ & $\begin{array}{c}8.0 \\
(4.1)\end{array}$ & $\begin{array}{c}4.9 \\
(2.2)\end{array}$ & $\begin{array}{l}24.7 \\
(4.3)\end{array}$ & $\begin{array}{c}8.9 \\
(4.4)\end{array}$ & $\begin{array}{c}3.8 \\
(1.2)\end{array}$ \\
\hline Spruce basal area & $\begin{array}{l}1.5 \\
(2.0)\end{array}$ & $\begin{array}{c}0.4 \\
(0.3)\end{array}$ & $\begin{array}{l}1.1 \\
(1.2)\end{array}$ & $\begin{array}{c}6.5 \\
(4.5)\end{array}$ & $\begin{array}{c}2.6 \\
(3.7)\end{array}$ & $\begin{array}{c}1.4 \\
(1.1)\end{array}$ & $\begin{array}{l}15.0 \\
(8.2)\end{array}$ & $\begin{array}{c}2.3 \\
(3.2)\end{array}$ & $\begin{array}{c}0.2 \\
(0.1)\end{array}$ \\
\hline Birch basal area & $\begin{array}{c}0.2 \\
(0.2)\end{array}$ & $\begin{array}{c}3.7 \\
(4.1)\end{array}$ & $\begin{array}{c}0.3 \\
(0.6)\end{array}$ & $\begin{array}{c}1.0 \\
(1.8)\end{array}$ & $\begin{array}{c}14.0 \\
(12.6)\end{array}$ & $\begin{array}{c}0.3 \\
(0.7)\end{array}$ & $\begin{array}{c}0.4 \\
(0.5)\end{array}$ & $\begin{array}{c}26.9 \\
(11.5)\end{array}$ & $\begin{array}{c}2.4 \\
(4.1)\end{array}$ \\
\hline Aspen basal area & $\begin{array}{c}0.1 \\
(0.1)\end{array}$ & $\begin{array}{c}0.4 \\
(0.8)\end{array}$ & $\begin{array}{c}1.9 \\
(2.4)\end{array}$ & $\begin{array}{c}0.7 \\
(1.5)\end{array}$ & $\begin{array}{c}0.1 \\
(0.1)\end{array}$ & $\begin{array}{c}8.8 \\
(5.2)\end{array}$ & $\begin{array}{c}0.0 \\
(0.0)\end{array}$ & $\begin{array}{c}1.3 \\
(2.7)\end{array}$ & $\begin{array}{l}31.0 \\
(3.1)\end{array}$ \\
\hline Shrubs basal area ${ }^{2}$ & $\begin{array}{c}2.9 \\
(2.4)\end{array}$ & $\begin{array}{c}1.9 \\
(1.7)\end{array}$ & $\begin{array}{c}3.7 \\
(3.4)\end{array}$ & $\begin{array}{c}3.0 \\
(3.4)\end{array}$ & $\begin{array}{c}1.8 \\
(2.2)\end{array}$ & $\begin{array}{l}1.8 \\
(2.6)\end{array}$ & $\begin{array}{c}0.5 \\
(0.5)\end{array}$ & $\begin{array}{c}3.4 \\
(3.0)\end{array}$ & $\begin{array}{c}0.9 \\
(1.0)\end{array}$ \\
\hline
\end{tabular}

$722{ }^{1}$ Averages that do not share a letter were significantly different based on a Tukey Honest Significance Difference 723 post-hoc test $(\mathrm{p}<0.05)$.

$724{ }^{2}$ Shrubs includes large deciduous shrubs, i.e. Alnus spp., Salix spp., and Betula spp.

725 
726 Table 2: Bryophyte taxa list, taxa code for the ordinations, functional type, and average percent cover in the forest types and

727 successional stages. Stands types are represented by PM: Picea mariana, BN: Betula neoalaskana, and PT: Populus tremuloides.

728 Successional stages are represented as early succession, mid-succession, and late succession.

\begin{tabular}{|c|c|c|c|c|c|c|c|c|c|c|c|c|}
\hline \multirow[t]{2}{*}{ Order } & \multirow[t]{2}{*}{ Family } & \multirow[t]{2}{*}{ Taxa name } & \multirow[t]{2}{*}{ Functional type $^{1}$} & \multicolumn{3}{|c|}{$0-20$ years } & \multicolumn{3}{|c|}{ 20-62 years } & \multicolumn{3}{|c|}{63 years +} \\
\hline & & & & PM & BN & PT & $\mathbf{P M}$ & BN & PT & PM & BN & PT \\
\hline \multirow{6}{*}{ Bryales } & \multirow{2}{*}{ Aulacomniaceae } & Aulacomnium palustre (Hedw.) Schwägr. & \multirow{2}{*}{ Acrocarpous mosses } & 10.3 & 3.1 & 1.7 & 10.8 & 0.9 & 0.5 & 10.6 & 0.0 & 0.0 \\
\hline & & Aulacomnium turgidum (Wahlenb.) Schwägr. & & 1.7 & 0.1 & 0.4 & 0.0 & 0.0 & 0.0 & 0.0 & 0.0 & 0.0 \\
\hline & \multirow{4}{*}{ Bryaceae } & Bryum spp. & \multirow{4}{*}{ Colonizer } & 3.2 & 2.7 & 0.1 & 0.0 & 0.0 & 0.1 & 0.0 & 0.0 & 0.0 \\
\hline & & Leptobryum pyriforme (Hedw.) Wilson & & 2.6 & 2.4 & 0.1 & 0.0 & 0.0 & 0.0 & 0.3 & 0.0 & 0.0 \\
\hline & & Pohlia sp. & & 0.0 & 0.0 & 0.0 & 0.0 & 0.0 & 0.7 & 0.0 & 0.0 & 0.0 \\
\hline & & Ceratodon purpureus (Hedw.) Brid. & & 34.7 & 32.5 & 41.2 & 0.7 & 0.0 & 2.3 & 0.0 & 0.0 & 0.0 \\
\hline \multirow{3}{*}{ Dicranales } & \multirow{3}{*}{ Dicranaceae } & Dicranum spp. & \multirow{3}{*}{ Acrocarpous mosses } & 0.5 & 0.1 & 0.0 & 0.3 & 1.4 & 0.3 & 0.2 & 3.5 & 0.3 \\
\hline & & Dicranum sp. & & 0.0 & 0.0 & 0.0 & 1.4 & 0.3 & 0.3 & 3.5 & 0.2 & 0.3 \\
\hline & & Dicranum undulatum Schrad. ex Brid. & & 7.0 & 9.0 & 13.0 & 21.0 & 7.0 & 14.0 & 5.0 & 4.0 & 3.0 \\
\hline \multirow{15}{*}{ Hypnales } & Amblystegiaceae & Sanionia uncinata $($ Hedw.) Loeske & \multirow{15}{*}{ Pleurocarpous mosses } & 0.2 & 0.0 & 0.2 & 0.0 & 0.0 & 0.0 & 0.0 & 0.0 & 0.0 \\
\hline & Brachytheciaceae & Tomentypnum nitens (Hedw.) Loeske & & 0.0 & 0.0 & 0.0 & 1.1 & 0.0 & 0.0 & 1.0 & 0.0 & 0.0 \\
\hline & Hylocomiacon & Hylocomium splendens (Hedw.) Schimp. & & 0.0 & 0.0 & 0.1 & 5.7 & 6.3 & 1.6 & 42.7 & 4.6 & 24.3 \\
\hline & пуюосо оmaceae & Pleurozium schreberi (Brid.) Mitt. & & 2.2 & 1.6 & 0.2 & 14.2 & 18.6 & 1.8 & 24.5 & 0.2 & 1.1 \\
\hline & \multirow{4}{*}{ Hypnaceae } & Нурпит spp. & & 0.1 & 0.0 & 0.1 & 0.0 & 0.0 & 0.0 & 0.0 & 0.0 & 0.0 \\
\hline & & Hypnum cupressiforme Hedw. & & 0.1 & 0.0 & 0.0 & 0.0 & 0.0 & 0.0 & 0.0 & 0.0 & 0.0 \\
\hline & & Hypnum plicatulum (Lindb.) A. Jaeger & & 0.0 & 0.0 & 0.1 & 0.0 & 0.0 & 0.0 & 0.0 & 0.0 & 0.0 \\
\hline & & Hypnum revolutum (Mitt.) Lindb. & & 0.0 & 0.0 & 0.1 & 0.0 & 0.0 & 0.0 & 0.0 & 0.0 & 0.0 \\
\hline & Rhytidiaceae & Rhytidium rugosum (Hedw.) Kindb. & & 0.0 & 0.0 & 0.1 & 0.2 & 0.0 & 2.1 & 0.0 & 0.0 & 0.0 \\
\hline & - & Hypnales & & 0.3 & 0.1 & 0.1 & 0.04 & 0.3 & 0.0 & 0.0 & 0.0 & 0.0 \\
\hline & Ambluctogino & Amblystegium $s p$. & & 0.0 & 0.1 & 0.0 & 0.0 & 0.0 & 0.0 & 0.0 & 0.0 & 0.0 \\
\hline & Ambiystegiaceae & Drepanocladus sp. & & 0.3 & 0.0 & 0.0 & 0.0 & 0.0 & 0.0 & 0.0 & 0.0 & 0.0 \\
\hline & Brachytheciaceae & Brachythecium sp. & & 0.0 & 0.0 & 0.1 & 0.0 & 0.0 & 0.0 & 0.0 & 0.0 & 0.0 \\
\hline & Thuidiaceae & Thuidium abietinum (Hedw.) Schimp. & & 0.0 & 0.0 & 0.0 & 0.04 & 0.0 & 0.0 & 0.0 & 0.0 & 0.0 \\
\hline & Hypnaceae & Ptilium crista-castrensis (Hedw.) De Not. & & 0.0 & 0.0 & 0.0 & 0.0 & 0.3 & 0.0 & 0.0 & 0.0 & 0.0 \\
\hline \multirow{4}{*}{ Polytrichales } & \multirow{4}{*}{ Polytrichaceae } & Polytrichum commune Hedw. & \multirow{4}{*}{ Colonizer } & 14.3 & 19.5 & 6.1 & 16.1 & 12.1 & 14.3 & 7.0 & 0.0 & 0.0 \\
\hline & & Polytrichum juniperinum Hedw. & & 13.7 & 10.9 & 29.8 & 0.00 & 0.0 & 0.0 & 0.0 & 0.0 & 0.0 \\
\hline & & Polytrichum piliferum Hedw. & & 0.0 & 2.8 & 0.0 & 0.0 & 0.0 & 0.0 & 0.0 & 0.0 & 0.0 \\
\hline & & Polytrichum strictum Menzies ex Brid. & & 0.2 & 1.9 & 0.0 & 0.0 & 0.0 & 0.0 & 0.0 & 0.0 & 0.0 \\
\hline \multirow{4}{*}{ Jungermanniales } & - & Jungermaniales & \multirow{5}{*}{ Liverwort } & 1.3 & 0.5 & 0.2 & 0.0 & 0.0 & 0.0 & 2.4 & 0.0 & 0.0 \\
\hline & Myliaceae & Mylia sp. & & 0.0 & 0.0 & 0.0 & 0.0 & 0.0 & 0.0 & 1.4 & 0.0 & 0.0 \\
\hline & Jungermanniaceae & Lophozia ventricosa (Dicks.) Dumort. cf. & & 1.3 & 0.5 & 0.2 & 0.0 & 0.0 & 0.0 & 1.0 & 0.0 & 0.0 \\
\hline & - & Unknown liverworts & & 0.6 & 0.0 & 0.0 & 0.0 & 0.0 & 0.0 & 0.0 & 0.0 & 0.0 \\
\hline Marchantiales & Marchantiaceae & Marchantia polymorpha $\mathrm{L}$. & & 3.9 & 9.5 & 0.0 & 0.0 & 0.0 & 0.1 & 0.0 & 0.0 & 0.0 \\
\hline Sphagnales & Sphagnaceae & Sphagnum spp. & Sphagnum & 1.4 & 0.6 & 1.4 & 6.6 & 1.5 & 0.0 & 29.4 & 0.0 & 1.4 \\
\hline- & - & Unknown moss 1 & & 0.0 & 0.0 & 0.0 & 0.1 & 0.2 & 0.1 & 0.0 & 0.0 & 0.0 \\
\hline- & - & Unknown moss 2 & Unknown mosses & 0.0 & 0.0 & 0.0 & 0.0 & 0.0 & 1.2 & 1.2 & 1.3 & 3.2 \\
\hline- & - & Unknown moss 3 & Unknown mosses & 0.0 & 0.0 & 0.0 & 3.1 & 4.0 & 0.8 & 3.0 & 0.6 & 4.8 \\
\hline- & - & Unknown moss 4 & & 0.0 & 0.0 & 0.0 & 0.8 & 3.1 & 0.0 & 0.0 & 0.0 & 0.0 \\
\hline
\end{tabular}


729 Table 3: Abundance of bryophytes grouped by functional types and compared according to forest

730 type and successional stage.

\begin{tabular}{|c|c|c|c|c|c|c|}
\hline $\begin{array}{l}\text { Functional } \\
\text { group }\end{array}$ & $\begin{array}{c}\text { Successional } \\
\text { stage }\end{array}$ & Forest type & $n$ & $\begin{array}{c}\text { Average } \\
\text { cover }(\%)\end{array}$ & $\begin{array}{c}\text { Standard } \\
\text { error }\end{array}$ & $\begin{array}{c}\text { Post hoc test } \\
\text { results }\end{array}$ \\
\hline \multirow{9}{*}{ 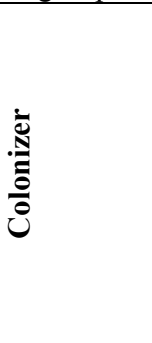 } & \multirow[t]{3}{*}{ Early } & Spruce & 7 & 60.5 & 6.6 & \multirow{3}{*}{ a } \\
\hline & & Birch & 9 & 62.2 & 5.6 & \\
\hline & & Aspen & 13 & 64.7 & 4.1 & \\
\hline & \multirow[t]{3}{*}{ Mid } & Spruce & 21 & 16.8 & 4.0 & \multirow{3}{*}{$\mathrm{b}$} \\
\hline & & Birch & 7 & 12.1 & 4.7 & \\
\hline & & Aspen & 14 & 17.0 & 4.3 & \\
\hline & \multirow[t]{3}{*}{ Late } & Spruce & 5 & 7.4 & 5.1 & \multirow{3}{*}{$\mathrm{b}$} \\
\hline & & Birch & 4 & 0.0 & 0.0 & \\
\hline & & Aspen & 3 & 0.0 & 0.0 & \\
\hline \multirow{9}{*}{ 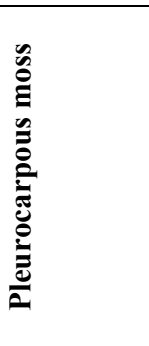 } & \multirow[t]{3}{*}{ Early } & Spruce & 7 & 2.9 & 1.9 & $\mathrm{a}$ \\
\hline & & Birch & 9 & 1.7 & 1.5 & a \\
\hline & & Aspen & 13 & 0.7 & 0.5 & $\mathrm{a}$ \\
\hline & \multirow[t]{3}{*}{ Mid } & Spruce & 21 & 19.4 & 3.8 & $\mathrm{a}$ \\
\hline & & Birch & 7 & 22.1 & 6.7 & $\mathrm{a}$ \\
\hline & & Aspen & 14 & 5.4 & 2.3 & $\mathrm{a}$ \\
\hline & \multirow[t]{3}{*}{ Late } & Spruce & 5 & 60.6 & 9.6 & $\mathrm{~b}$ \\
\hline & & Birch & 4 & 4.8 & 2.8 & $\mathrm{a}$ \\
\hline & & Aspen & 3 & 25.3 & 6.6 & $\mathrm{a}$ \\
\hline \multirow{9}{*}{ 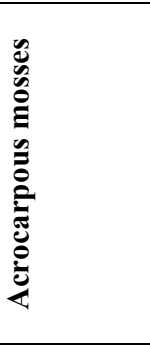 } & \multirow[t]{3}{*}{ Early } & Spruce & 7 & 11.2 & 4.1 & $\mathrm{a}$ \\
\hline & & Birch & 9 & 3.7 & 1.4 & $\mathrm{~b}$ \\
\hline & & Aspen & 13 & 1.8 & 1.1 & $\mathrm{~b}$ \\
\hline & \multirow[t]{3}{*}{ Mid } & Spruce & 21 & 12.2 & 3.4 & $\mathrm{a}$ \\
\hline & & Birch & 7 & 1.3 & 1.0 & $\mathrm{~b}$ \\
\hline & & Aspen & 14 & 0.8 & 0.4 & $\mathrm{~b}$ \\
\hline & \multirow[t]{3}{*}{ Late } & Spruce & 5 & 13.3 & 1.9 & $\mathrm{a}$ \\
\hline & & Birch & 4 & 0.2 & 0.2 & $\mathrm{~b}$ \\
\hline & & Aspen & 3 & 0.3 & 0.3 & $\mathrm{~b}$ \\
\hline \multirow{9}{*}{ 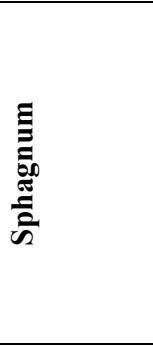 } & \multirow[t]{3}{*}{ Early } & Spruce & 7 & 1.4 & 0.9 & NA \\
\hline & & Birch & 9 & 0.6 & 0.6 & NA \\
\hline & & Aspen & 13 & 1.4 & 1.2 & NA \\
\hline & \multirow[t]{3}{*}{ Mid } & Spruce & 21 & 6.6 & 3.4 & NA \\
\hline & & Birch & 7 & 1.5 & 1.4 & NA \\
\hline & & Aspen & 14 & 0.0 & 0.0 & NA \\
\hline & \multirow[t]{3}{*}{ Late } & Spruce & 5 & 29.4 & 16.3 & NA \\
\hline & & Birch & 4 & 0.0 & 0.0 & NA \\
\hline & & Aspen & 3 & 0.0 & 0.0 & NA \\
\hline \multirow{9}{*}{ 晜 } & \multirow[t]{3}{*}{ Early } & Spruce & 7 & 5.6 & 2.8 & NA \\
\hline & & Birch & 9 & 10.0 & 7.1 & NA \\
\hline & & Aspen & 13 & 0.2 & 0.2 & NA \\
\hline & \multirow[t]{3}{*}{ Mid } & Spruce & 21 & 0.0 & 0.0 & NA \\
\hline & & Birch & 7 & 0.0 & 0.0 & NA \\
\hline & & Aspen & 14 & 0.1 & 0.1 & NA \\
\hline & \multirow[t]{3}{*}{ Late } & Spruce & 5 & 2.4 & 1.5 & NA \\
\hline & & Birch & 4 & 0.0 & 0.0 & NA \\
\hline & & Aspen & 3 & 0.0 & 0.0 & NA \\
\hline
\end{tabular}

$731{ }^{1}$ Tukey post hoc tests were conducted after two-way ANOVA by permutation. Relevant ANOVA results are 732 presented in Supplementary material 3. Different letters indicate a significant difference among forest cover types 733 or successional stages for that functional type $(\alpha=0.05)$. 
735 Table 4: Axis loadings of environmental and stand covariates on the two NMDS axes.

\begin{tabular}{|c|c|c|c|c|}
\hline & NMDS 1 & NMDS 2 & $\mathbf{r}^{2}$ & $\operatorname{Pr}(>r)^{4}$ \\
\hline Age (years) ${ }^{\top}$ & 0.90845 & 0.41798 & 0.529 & $0.001^{*}$ \\
\hline Bare ground cover $(\%)$ & -0.91954 & -0.39299 & 0.364 & $0.001 *$ \\
\hline Coarse woody debris cover (\%) & -0.9674 & 0.25327 & 0.2265 & $0.001 *$ \\
\hline Leaf litter cover $(\%)$ & -0.27805 & 0.96057 & 0.2928 & $0.001 *$ \\
\hline Deciduous index (DecIV) ${ }^{2}$ & -0.71815 & 0.69589 & 0.3418 & $0.001 *$ \\
\hline Black spruce basal area ${ }^{3}$ & 0.92859 & -0.3711 & 0.4283 & $0.001 *$ \\
\hline Aspen basal area ${ }^{3}$ & 0.21623 & 0.97634 & 0.2048 & $0.001 *$ \\
\hline Organic layer depth (cm) & 0.46833 & -0.88355 & 0.3708 & $0.001 *$ \\
\hline Moisture class (six classes) & 0.99917 & -0.04074 & 0.2505 & $0.001 *$ \\
\hline Vascular plant cover $(\%)$ & -0.48946 & -0.87202 & 0.1311 & $0.005^{*}$ \\
\hline Birch basal area ${ }^{3}$ & 0.25952 & 0.96574 & 0.1281 & $0.009^{*}$ \\
\hline $\mathrm{pH}$ & -0.9967 & -0.08121 & 0.0538 & 0.101 \\
\hline Elevation (m) & -0.79951 & 0.60066 & 0.0315 & 0.283 \\
\hline Lichen cover $(\%)$ & -0.1675 & -0.98587 & 0.0236 & 0.374 \\
\hline Heatload & -0.99695 & 0.07805 & 0.0171 & 0.497 \\
\hline Shrub basal area ${ }^{4}$ & -0.99992 & -0.01245 & 0.01 & 0.623 \\
\hline
\end{tabular}

736 * Significant correlations at $\alpha=0.05,999$ permutations.

$737 \quad{ }^{1}$ Years since fire (age) based on sampling year minus year burned.

$738{ }^{2}$ Deciduous Importance Value (IV). See Alexander et al. (2012) for calculation.

$739{ }^{3}$ Total basal area calculated for each taxa group $\left(\mathrm{m}^{2}\right.$ basal area per $\mathrm{m}^{2}$ sample area). Tall shrubs included Betula 740 spp., Alnus spp., and Salix spp.

$741{ }^{4}$ The $^{2}$ values are Pearson correlation coefficients, and significance of the correlations were obtained from 999 742 permutations.

743 
744 Figure 1: Variations in total bryophyte cover (\%) versus time after fire in forest stands dominated

745 by black spruce (blue), Alaska paper birch (green) or trembling aspen (yellow). Points represent

746 percent cover for each of the 83 sampled stands, fitted with LOESS (locally weighted scatterplot

747 smoothing) curves with a smoothing parameter of 1 for each series of points. Shadings represent

748 the $95 \%$ confidence interval.

749 Figure 2: Variations in bryophyte cover grouped into functional types of a) colonizers, b)

750 pleurocarpous (feather) mosses and c) other true mosses, plotted against time since fire (years) in

751 spruce (blue), birch (green), and aspen (yellow) stands ( $\mathrm{n}=83$ ). LOESS curves were fit to each

752 series of points with a smoothing parameter of 1 . Shadings represent the $95 \%$ confidence

753 interval.

754 Figure 3: Distribution of the stands in a two-dimensional NMDS ordination (stress of 0.18, 100

755 iterations, Bray-Curtis distance) based on bryophyte community composition (83 stands and 25

756 taxa). The two axes capture $38 \%$ of the variation in the original ranked matrix, with axes 1 and 2

757 capturing $33.1 \%$ and $6.5 \%$ of the variation, respectively. Individual points represent sample units

758 (stands) grouped by forest type: spruce (blue, triangles), birch (green, circles) and aspen (yellow,

759 squares). All stands are represented on each of the four panels, irrespective of age. Polygons in

760 each panel are drawn to encompass stands representing a) early succession (8-20 years since

761 fire), b) mid-succession (20-60 years since fire), and c) late succession (more than 60 years since

762 fire) (color code same as stands); in panel d) black vectors show correlations with environmental

763 and stand covariates.

764 Figure 4: Univariate regression tree partitioning variation in total bryophyte cover (\%).

765 Thresholds associated with environmental variables for each split are shown next to each node of 
766 the tree, along with the percentage of total variation explained by each split. The percent of the

767 variation explained by the tree is $61.2 \%$ and the cross-validated error to estimate prediction error

768 on new samples is $74.6 \%$. Each terminal group is shown with its average bryophyte cover (\%),

769 age (years since fire), and number of stands; pie charts show the relative abundance of forest

770 types in each group.

771 Figure 5: Variations in total bryophyte cover (\%) versus leaf litter cover $(\%)$ in stands $(\mathrm{n}=83)$

772 dominated by spruce (blue), birch (green) or aspen (yellow). The dashed vertical line identifies

773 the $75.6 \%$ threshold in leaf litter cover identified by the regression tree analysis.

774 Figure 6: Multivariate regression trees partitioning the Bray-Curtis distances among stands $(n=$

775 83) calculated from a) functional group cover $(n=5)$ and b) bryophyte taxa composition $(n=$

776 25). Thresholds associated with environmental variables for each split are shown next to each

777 node of the tree, along with the percentage of total variation explained by each split. The percent

778 of the variation explained by the tree in a) is $64.8 \%$ and the cross validated error is $52.5 \%$ for a)

779 and the percent variation explained by the tree in b) is $43.5 \%$, the error is $56.5 \%$, and the cross

780 validated error is $67.1 \%$. Each terminal group is shown with its average bryophyte cover $(\%)$,

781 age (years since fire), and number of stands; pie charts show the relative abundance of forest

782 types in each group. 
783 Supplementary material 1: Characteristics of 83 forest stands sampled across boreal forests of interior Alaska, grouped by fire name (for sites located 784 in known burned areas) or as mature stands (unburned since at least 1945).

\begin{tabular}{|c|c|c|c|c|c|c|c|c|c|c|c|c|c|c|c|}
\hline Fire name & $\begin{array}{l}\text { Burn } \\
\text { year }\end{array}$ & $\begin{array}{c}\text { Year } \\
\text { sampled }\end{array}$ & $\begin{array}{l}\text { Since } \\
\text { fire } \\
(y r)^{1}\end{array}$ & $\begin{array}{c}\text { Slope } \\
\left({ }^{\circ}\right)\end{array}$ & $\begin{array}{c}\text { Orientation } \\
\left({ }^{\circ}\right)\end{array}$ & $\begin{array}{l}\text { Elevation } \\
\quad(\mathrm{m})\end{array}$ & $\begin{array}{l}\text { Forest } \\
\text { type }^{2}\end{array}$ & $\operatorname{DeclV}^{3}$ & $\begin{array}{c}\text { Black } \\
\text { spruce } \\
\text { biomass } \\
\left(\mathrm{g} / \mathrm{m}^{2}\right)^{4}\end{array}$ & $\begin{array}{c}\text { Alaska } \\
\text { paper } \\
\text { birch } \\
\text { biomass } \\
\left(\mathrm{g} / \mathrm{m}^{2}\right)^{4}\end{array}$ & $\begin{array}{c}\text { Tremblin } \\
\text { g aspen } \\
\text { biomass } \\
\left(\mathrm{g} / \mathrm{m}^{2}\right)^{4}\end{array}$ & $\begin{array}{c}\text { Large } \\
\text { shrubs } \\
\text { biomass } \\
\left(\mathrm{g} / \mathrm{m}^{2}\right)^{5}\end{array}$ & $\begin{array}{l}\text { Leaf } \\
\text { litter } \\
\text { cover } \\
(\%)\end{array}$ & $\begin{array}{l}\text { Bryophyte } \\
\text { cover (\%) }\end{array}$ & $\begin{array}{c}\text { Organic } \\
\text { layer } \\
\text { depth } \\
(\mathrm{cm})\end{array}$ \\
\hline \multirow{3}{*}{ Parks Highway } & 2006 & 2014 & 8 & 0 & Flat & 125 & PM & 2.35 & 8.5 & 6.3 & 0.8 & 59.4 & 69.6 & 72 & 10.0 \\
\hline & 2006 & 2014 & 8 & 0 & Flat & 141 & $\mathrm{BN}$ & 2.38 & 4.8 & 13.2 & 4.3 & 21.6 & 44.8 & 94.4 & 10.4 \\
\hline & 2006 & 2014 & 8 & 0 & Flat & 142 & $\mathrm{BN}$ & 2.66 & 2.7 & 7.1 & 0.7 & 23.5 & 70.4 & 49.6 & 12.0 \\
\hline \multirow{5}{*}{ Boundary } & 2004 & 2013 & 9 & 3 & 139 & 489 & $\mathrm{BN}$ & 2.67 & 8.2 & 134.8 & 50.9 & 38.8 & 56.8 & 74.4 & 8.9 \\
\hline & 2004 & 2013 & 9 & 13 & 225 & 256 & $\mathrm{BN}$ & 2.82 & 50.6 & 1209.6 & 263.4 & 76.7 & 80.8 & 73.6 & 11.4 \\
\hline & 2004 & 2013 & 9 & 4 & 203 & 240 & PM & 1.9 & 28.2 & 7.7 & 11.5 & 15.2 & 74.4 & 60 & 16.1 \\
\hline & 2004 & 2013 & 9 & 13 & 315 & 260 & PT & 1.8 & 1.0 & 0.0 & 1.0 & 17.0 & 58.4 & 85.6 & 18.1 \\
\hline & 2004 & 2013 & 9 & 6 & 135 & 311 & PT & 2.74 & 11.4 & 84.4 & 241.4 & 31.1 & 67.2 & 86.4 & 8.8 \\
\hline \multirow{3}{*}{ Fish Creek } & 2005 & 2014 & 9 & 0 & Flat & 296 & PM & 2.3 & 21.6 & 18.9 & 0.3 & 115.0 & 69.6 & 83.2 & 8.1 \\
\hline & 2005 & 2014 & 9 & 4 & 270 & 267 & $\mathrm{BN}$ & 2.44 & 22.0 & 108.2 & 4.3 & 512.3 & 51.2 & 84 & 8.1 \\
\hline & 2005 & 2014 & 9 & 2 & 203 & 224 & PM & 2.2 & 53.0 & 12.9 & 0.3 & 177.3 & 63.2 & 61.6 & 4.2 \\
\hline \multirow{3}{*}{ Chicken 1} & 2004 & 2014 & 10 & 4 & 315 & 718 & PT & 2.99 & 0.6 & 7.1 & 13.4 & 138.8 & 81.6 & 72 & 5.9 \\
\hline & 2004 & 2014 & 10 & 0 & Flat & 651 & PM & 2.88 & 3.5 & 0.0 & 0.0 & 202.7 & 72 & 68 & 9.6 \\
\hline & 2004 & 2014 & 10 & 4 & 180 & 657 & PT & 2.63 & 7.5 & 0.0 & 17.1 & 40.7 & 80 & 60.8 & 7.9 \\
\hline \multirow{4}{*}{ Porcupine } & 2004 & 2014 & 10 & 6 & 225 & 927 & PT & 2.97 & 0.3 & 0.0 & 42.0 & 106.4 & 70.4 & 68.8 & 6.8 \\
\hline & 2004 & 2014 & 10 & 5 & 45 & 804 & PT & 2.83 & 3.6 & 1.5 & 10.7 & FALSE & 76 & 44.8 & 7.7 \\
\hline & 2004 & 2014 & 10 & 5 & 45 & 708 & $\mathrm{BN}$ & 2.66 & 35.6 & 169.9 & 21.4 & 151.2 & 60.8 & 63.2 & 7.3 \\
\hline & 2004 & 2014 & 10 & 8 & 135 & 622 & $\mathrm{BN}$ & 2.66 & 29.3 & 142.5 & 22.4 & 132.7 & 60 & 89.6 & 7.5 \\
\hline \multirow{3}{*}{ Westfork } & 2002 & 2014 & 12 & 0 & Flat & 302 & $\mathrm{BN}$ & 2.26 & 1.5 & 4.6 & 0.3 & 1.1 & 74.4 & 61.6 & 11.7 \\
\hline & 2002 & 2014 & 12 & 0 & Flat & 319 & PM & 2.17 & 618.8 & 1.2 & 16.5 & 328.5 & 65.6 & 54.4 & 9.6 \\
\hline & 2002 & 2014 & 12 & 25 & 135 & 341 & $\mathrm{BN}$ & 2.37 & 12.8 & 86.8 & 0.1 & 151.2 & 64 & 51.2 & 12.2 \\
\hline \multirow{4}{*}{ Donnelly Flats } & 1999 & 2014 & 15 & 0 & Flat & 459 & PT & 1.67 & 18.4 & 1.5 & 54.4 & 21.4 & 88.8 & 82.4 & 3.9 \\
\hline & 1999 & 2014 & 15 & 0 & Flat & 521 & PM & 1.46 & 82.6 & 0.0 & 3.2 & 0.6 & 64 & 87.2 & 10.0 \\
\hline & 1999 & 2014 & 15 & 0 & Flat & 457 & PT & 2.44 & 31.3 & 1.0 & 108.9 & 69.0 & 64 & 80.8 & 3.6 \\
\hline & 1999 & 2014 & 15 & 0 & Flat & 477 & PT & 2.23 & 139.4 & 123.3 & 636.7 & 708.0 & 70.4 & 63.2 & 6.0 \\
\hline \multirow{4}{*}{ Hajdukovich } & 1994 & 2013 & 19 & 0 & Flat & 468 & PT & 2.61 & 8.0 & 4.4 & 26.8 & 66.7 & 84.8 & 60 & 10.2 \\
\hline & 1994 & 2013 & 19 & 0 & Flat & 456 & PT & 2.53 & 84.5 & 2.2 & 1307.4 & 179.2 & 77.6 & 45.6 & 4.2 \\
\hline & 1994 & 2013 & 19 & 0 & Flat & 466 & PT & 2.37 & 198.9 & 91.5 & 229.9 & 200.3 & 75.2 & 67.2 & 9.1 \\
\hline & 1994 & 2013 & 19 & 0 & Flat & 421 & PT & 2.72 & 155.5 & 15.8 & 242.6 & 602.3 & 77.6 & 44.8 & 7.3 \\
\hline \multirow{3}{*}{ Tok River } & 1990 & 2010 & 20 & 1 & 297 & 500 & PT & 2.89 & 28.8 & 0.0 & 1659.2 & 863.4 & 85.6 & 8 & 8.0 \\
\hline & 1990 & 2010 & 20 & 0 & Flat & 504 & PM & 1.82 & 768.3 & 1.7 & 23.6 & 54.8 & 32.8 & 54.4 & 12.4 \\
\hline & 1990 & 2010 & 20 & 0 & Flat & 503 & PT & 2.23 & 183.0 & 0.0 & 219.8 & 106.9 & 77.6 & 24 & 7.7 \\
\hline \multirow{3}{*}{ Granite Creek } & 1987 & 2008 & 21 & 1 & 54 & 385 & PT & 2.59 & 76.6 & 13.9 & 2135.8 & 141.8 & 59.2 & 20 & 3.0 \\
\hline & 1987 & 2008 & 21 & 0 & 45 & 383 & PT & 2.72 & 26.9 & 0.0 & 290.1 & 147.4 & 30.4 & 43.2 & 8.0 \\
\hline & 1987 & 2008 & 21 & 1 & 20 & 436 & PM & 1.98 & 159.2 & 0.0 & 91.4 & 132.9 & 41.6 & 26.4 & 6.0 \\
\hline Slate Creek & 1987 & 2009 & 22 & 8 & 68 & 550 & PM & 0.21 & 276.4 & 0.0 & 0.0 & 0.3 & 36.8 & 68 & 18.8 \\
\hline
\end{tabular}




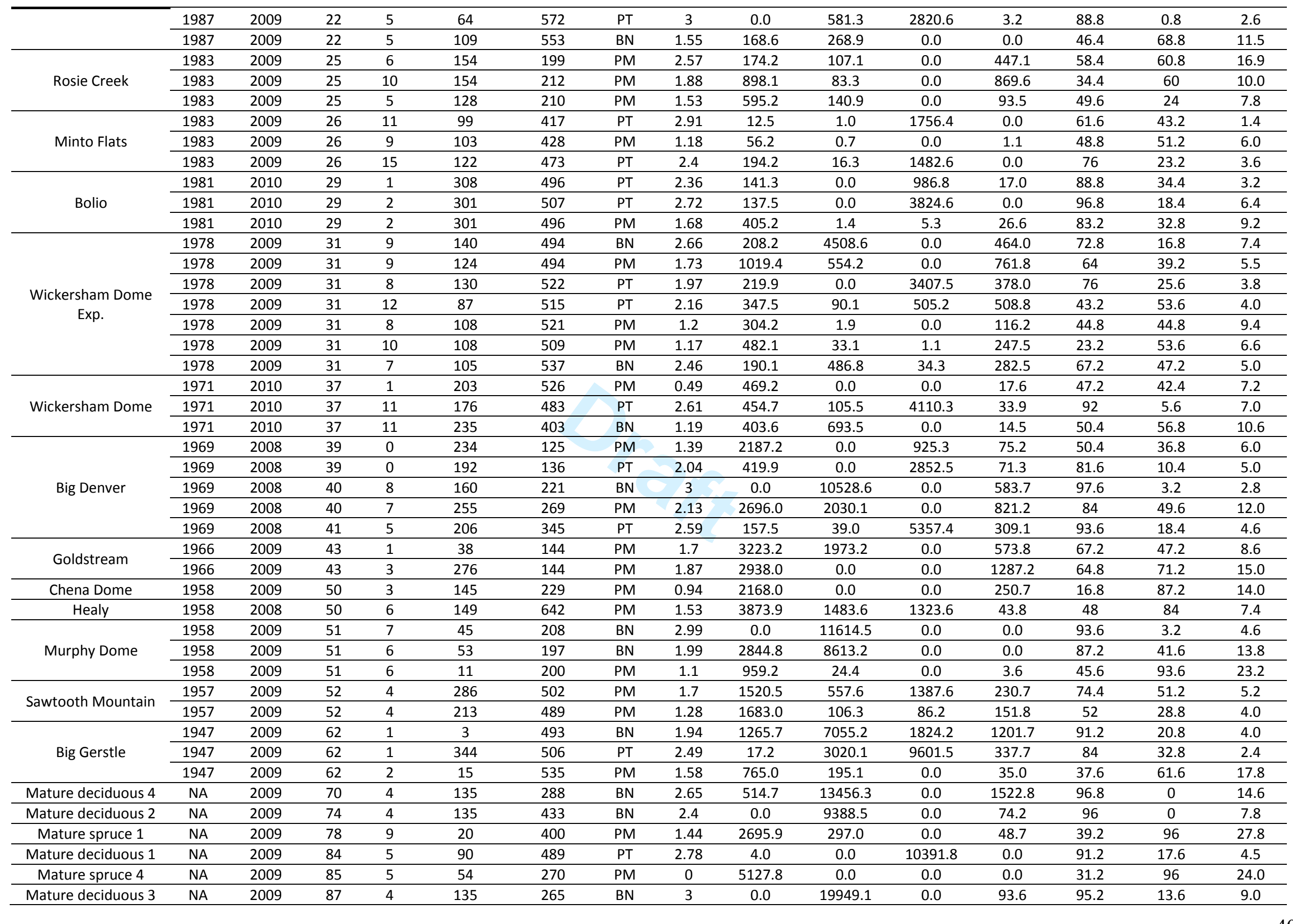




\begin{tabular}{|c|c|c|c|c|c|c|c|c|c|c|c|c|c|c|c|}
\hline Mature deciduous 5 & NA & 2009 & 120 & 6 & 11 & 519 & PT & 2.67 & 12.1 & 0.0 & 12712.6 & 111.9 & 88.8 & 44.8 & 4.4 \\
\hline Mature spruce 3 & NA & 2009 & 138 & 0 & 0 & 485 & PM & 0 & 4906.9 & 0.0 & 0.0 & 0.0 & 12.8 & 98.4 & 28.6 \\
\hline Mature spruce 2 & NA & 2009 & 163 & 0 & 0 & 480 & PM & 1.62 & 6585.0 & 0.0 & 0.0 & 52.9 & 48 & 86.4 & 25.4 \\
\hline
\end{tabular}

Notes: $\mathrm{NA}=$ No data. $\mathrm{BN}=$ Alaska paper birch, PM = black spruce, PT = trembling aspen. Flat = Stands were on flat ground so do not have slope or aspect.

${ }^{1}$ Years since fire (age) based on sampling year minus year burned from historic fire records, or tree rings in the case of some of the oldest stands.

${ }^{2}$ Forest type based on the dominant contribution to total standing biomass. See Alexander et al. (2012) for calculation.

${ }^{3}$ Deciduous Importance Value (IV). See Alexander et al. (2012) for calculation.

${ }^{4}$ Estimated from density and basal area using allometric equations presented in Alexander et al. (2012).

${ }^{5}$ Estimated from density and basal area of large shrubs (Alnus spp., Salix spp. and Betula spp.) using allometric equations in Berner et al. (2015). 
793 Supplementary material 2: Results from the two-way ANOVA on total bryophyte cover

794 compared between the three forest types (black spruce, Alaskan paper birch, and trembling

795 aspen) and the three post-fire successional periods (early, mid-, and late succession). This

796 ANOVA used a type III sums of squares in R to address the unbalanced data.

\begin{tabular}{lcccc}
\hline & Sum of squares & $\begin{array}{c}\text { Degrees of } \\
\text { freedom }\end{array}$ & F value & $p$ \\
\hline Forest type & 137 & 2 & 0.236 & 0.791 \\
$\begin{array}{l}\text { Successional } \\
\text { stage }\end{array}$ & 12414 & 2 & 21.345 & $<0.0001 *$ \\
$\begin{array}{l}\text { Interaction } \\
\text { Residuals }\end{array}$ & 10836 & 4 & 9.316 & $<0.0001 *$ \\
\hline * indicates significance at $\alpha=0.05$ & 74 & & \\
\hline
\end{tabular}


799 Supplementary material 3: Results from the two-way unbalanced ANOVAs by permutation

800 (4999) conducted on the three major bryophyte functional groups compared between the three

801 forest types (black spruce, Alaskan paper birch, and trembling aspen) and the three post-fire

802 successional periods (early, mid-, and late succession). This ANOVA used a type III sums of

803 squares in $\mathrm{R}$ to address the unbalanced data.

804

a) Colonizers

\begin{tabular}{lcccc}
\hline & Mean squares & $\begin{array}{c}\text { Degrees of } \\
\text { freedom }\end{array}$ & F statistic & $p$ \\
\hline $\begin{array}{l}\text { Forest type } \\
\text { Successional }\end{array}$ & 1.494 & 2 & 0.251 & 0.7776 \\
stage & 545.229 & 2 & 91.435 & $0.0002^{*}$ \\
Interaction & 2.834 & 4 & 0.916 & 0.9154 \\
Residuals & 220.632 & 74 & & \\
\hline
\end{tabular}

805

806

b) Feather mosses

\begin{tabular}{lcccc}
\hline & Mean squares & $\begin{array}{c}\text { Degrees of } \\
\text { freedom }\end{array}$ & F statistic & $p$ \\
\hline Forest type & 53.545 & 2 & 14.272 & $<0.0001 *$ \\
$\begin{array}{l}\text { Successional } \\
\text { stage }\end{array}$ & 86.584 & 2 & 23.079 & $<0.0001 *$ \\
Interaction & 75.869 & 4 & 10.111 & $<0.0001 *$ \\
Residuals & 138.810 & 74 & & \\
\hline
\end{tabular}

807

808

\begin{tabular}{lcccc}
\multicolumn{1}{c}{ c) } & Acrocarpous mosses & & & \\
\hline & Mean squares & $\begin{array}{l}\text { Degrees of } \\
\text { freedom }\end{array}$ & F statistic & $\boldsymbol{p}$ \\
\hline Forest type & 20.517 & 2 & 10.460 & $0.0014^{*}$ \\
Successional & 0.159 & 2 & 0.081 & 0.9248 \\
stage & 0.631 & 4 & 0.161 & 0.9488 \\
Interaction & 72.573 & 74 & & \\
Residuals & & & & \\
\hline
\end{tabular}

809

810

811

812

813 
814 Supplementary material 4: Results from the two-way unbalanced ANOVA on taxa composition

815 data compared between the three forest types (black spruce, Alaskan paper birch, and trembling

816 aspen) and the three post-fire successional periods (early, mid-, and late succession).

828

a) Results from the 2 way unbalanced ANOVA with permutations (4999) on taxa composition data. Similar results were obtained by using a Hellinger transformation on species data, or using a permutation ANOVA with Bray-Curtis distance not accounting for unbalanced data.

\begin{tabular}{lcccc}
\hline & $\begin{array}{c}\text { Degrees of } \\
\text { freedom }\end{array}$ & Variance & F statistic & $\boldsymbol{p}$ \\
\hline Forest type & 2 & 93.71 & 3.729 & $0.0006^{*}$ \\
$\begin{array}{l}\text { Successional } \\
\text { stage }\end{array}$ & 2 & 438.75 & 17.461 & $0.0002^{*}$ \\
Interaction & 4 & 110.28 & 2.194 & $0.0030^{*}$ \\
Residuals & 74 & 929.72 & & \\
\hline
\end{tabular}

b) ANOVA by permutations (4999) comparing bryophyte taxa composition among forest types within the early succession stands.

\begin{tabular}{lcccc}
\hline & $\begin{array}{c}\text { Degrees of } \\
\text { freedom }\end{array}$ & Sum of squares & F statistic & $\boldsymbol{p}$ \\
\hline Forest type & 2 & 0.443 & 1.888 & 0.0572 \\
Residuals & 26 & 3.049 & & \\
Total & 28 & 3.491 & & \\
\hline
\end{tabular}

c) ANOVA by permutations (4999) comparing bryophyte taxa composition among forest types within the mid-succession stands, followed by pairwise comparisons using the Bonferonni correction for multiple comparisons.

\begin{tabular}{lcccc}
\hline & $\begin{array}{c}\text { Degrees of } \\
\text { freedom }\end{array}$ & Sum of squares & F statistic & $p$ \\
\hline Forest type & 2 & 1.394 & 2.848 & $0.0004^{*}$ \\
Residuals & 39 & 9.542 & & \\
Total & 41 & 10.935 & & \\
\hline
\end{tabular}

\begin{tabular}{lcc}
\hline $\begin{array}{c}\text { Post hoc pairwise } \\
\text { comparisons }\end{array}$ & F statistic & $\begin{array}{c}\text { Adjusted } \\
\boldsymbol{p}\end{array}$ \\
\hline Spruce vs. Aspen & 4.171 & $0.009^{*}$ \\
Spruce vs. Birch & 1.506 & 0.471 \\
Aspen vs. Birch & 2.306 & 0.141 \\
\hline
\end{tabular}


d) ANOVA by permutations (4999) comparing bryophyte taxa composition among forest types within the late succession stands, followed by pairwise comparisons using

\begin{tabular}{lcccc}
\hline & $\begin{array}{c}\text { Degrees of } \\
\text { freedom }\end{array}$ & Sum of squares & F statistic & $\boldsymbol{p}$ \\
\hline Forest type & 2 & 4.429 & 4.298 & $0.0008^{*}$ \\
Residuals & 9 & 1.497 & & \\
Total & 11 & 2.916 & & \\
\hline
\end{tabular}

833

834

\begin{tabular}{lcc}
\hline $\begin{array}{c}\text { Post hoc pairwise } \\
\text { comparisons }\end{array}$ & F statistic & $\begin{array}{c}\text { Adjusted } \\
\boldsymbol{p}\end{array}$ \\
\hline Spruce vs. Aspen & 3.849 & 0.153 \\
Spruce vs. Birch & 5.785 & 0.030 \\
Aspen vs. Birch & 2.601 & 0.585 \\
\hline
\end{tabular}

835

836

837

838

839 
1 Supplementary Table S1: Characteristics of 83 forest stands sampled across boreal forests of interior Alaska, grouped by fire name (for sites located 2 in known burned areas) or as mature stands (unburned since at least 1945).

\begin{tabular}{|c|c|c|c|c|c|c|c|c|c|c|c|c|c|c|c|}
\hline Fire name & $\begin{array}{l}\text { Burn } \\
\text { year }\end{array}$ & $\begin{array}{c}\text { Year } \\
\text { sampled }\end{array}$ & $\begin{array}{l}\text { Since } \\
\text { fire } \\
(y r)^{1}\end{array}$ & $\begin{array}{c}\text { Slope } \\
\left({ }^{\circ}\right)\end{array}$ & $\begin{array}{c}\text { Orientatio } \\
n\left(\left(^{\circ}\right)\right.\end{array}$ & $\begin{array}{c}\text { Elevatio } \\
n(m)\end{array}$ & $\begin{array}{l}\text { Forest } \\
\text { type }^{2}\end{array}$ & DeclV $^{3}$ & $\begin{array}{c}\text { Black } \\
\text { spruce } \\
\text { biomass } \\
\left(\mathrm{g} / \mathrm{m}^{2}\right)^{4}\end{array}$ & $\begin{array}{c}\text { Alaska } \\
\text { paper } \\
\text { birch } \\
\text { biomass } \\
\left(\mathrm{g} / \mathrm{m}^{2}\right)^{4}\end{array}$ & $\begin{array}{l}\text { Tremblin } \\
\text { g aspen } \\
\text { biomass } \\
\left(\mathrm{g} / \mathrm{m}^{2}\right)^{4}\end{array}$ & $\begin{array}{c}\text { Large } \\
\text { shrubs } \\
\text { biomass } \\
\left(\mathrm{g} / \mathrm{m}^{2}\right)^{5}\end{array}$ & $\begin{array}{l}\text { Leaf } \\
\text { litter } \\
\text { cover } \\
(\%)\end{array}$ & $\begin{array}{c}\text { Bryophyt } \\
\text { e cover } \\
(\%)\end{array}$ & $\begin{array}{c}\text { Organic } \\
\text { layer } \\
\text { depth } \\
(\mathrm{cm})\end{array}$ \\
\hline \multirow{3}{*}{ Parks Highway } & 2006 & 2014 & 8 & 0 & Flat & 125 & PM & 2.35 & 8.5 & 6.3 & 0.8 & 59.4 & 69.6 & 72 & 10.0 \\
\hline & 2006 & 2014 & 8 & 0 & Flat & 141 & $\mathrm{BN}$ & 2.38 & 4.8 & 13.2 & 4.3 & 21.6 & 44.8 & 94.4 & 10.4 \\
\hline & 2006 & 2014 & 8 & 0 & Flat & 142 & $\mathrm{BN}$ & 2.66 & 2.7 & 7.1 & 0.7 & 23.5 & 70.4 & 49.6 & 12.0 \\
\hline \multirow{5}{*}{ Boundary } & 2004 & 2013 & 9 & 3 & 139 & 489 & $\mathrm{BN}$ & 2.67 & 8.2 & 134.8 & 50.9 & 38.8 & 56.8 & 74.4 & 8.9 \\
\hline & 2004 & 2013 & 9 & 13 & 225 & 256 & $\mathrm{BN}$ & 2.82 & 50.6 & 1209.6 & 263.4 & 76.7 & 80.8 & 73.6 & 11.4 \\
\hline & 2004 & 2013 & 9 & 4 & 203 & 240 & PM & 1.9 & 28.2 & 7.7 & 11.5 & 15.2 & 74.4 & 60 & 16.1 \\
\hline & 2004 & 2013 & 9 & 13 & 315 & 260 & PT & 1.8 & 1.0 & 0.0 & 1.0 & 17.0 & 58.4 & 85.6 & 18.1 \\
\hline & 2004 & 2013 & 9 & 6 & 135 & 311 & PT & 2.74 & 11.4 & 84.4 & 241.4 & 31.1 & 67.2 & 86.4 & 8.8 \\
\hline \multirow{3}{*}{ Fish Creek } & 2005 & 2014 & 9 & 0 & Flat & 296 & PM & 2.3 & 21.6 & 18.9 & 0.3 & 115.0 & 69.6 & 83.2 & 8.1 \\
\hline & 2005 & 2014 & 9 & 4 & 270 & 267 & $\mathrm{BN}$ & 2.44 & 22.0 & 108.2 & 4.3 & 512.3 & 51.2 & 84 & 8.1 \\
\hline & 2005 & 2014 & 9 & 2 & 203 & 224 & PM & 2.2 & 53.0 & 12.9 & 0.3 & 177.3 & 63.2 & 61.6 & 4.2 \\
\hline \multirow{3}{*}{ Chicken 1} & 2004 & 2014 & 10 & 4 & 315 & 718 & PT & 2.99 & 0.6 & 7.1 & 13.4 & 138.8 & 81.6 & 72 & 5.9 \\
\hline & 2004 & 2014 & 10 & 0 & Flat & 651 & PM & 2.88 & 3.5 & 0.0 & 0.0 & 202.7 & 72 & 68 & 9.6 \\
\hline & 2004 & 2014 & 10 & 4 & 180 & 657 & PT & 2.63 & 7.5 & 0.0 & 17.1 & 40.7 & 80 & 60.8 & 7.9 \\
\hline \multirow{4}{*}{ Porcupine } & 2004 & 2014 & 10 & 6 & 225 & 927 & PT & 2.97 & 0.3 & 0.0 & 42.0 & 106.4 & 70.4 & 68.8 & 6.8 \\
\hline & 2004 & 2014 & 10 & 5 & 45 & 804 & PT & 2.83 & 3.6 & 1.5 & 10.7 & FALSE & 76 & 44.8 & 7.7 \\
\hline & 2004 & 2014 & 10 & 5 & 45 & 708 & $\mathrm{BN}$ & 2.66 & 35.6 & 169.9 & 21.4 & 151.2 & 60.8 & 63.2 & 7.3 \\
\hline & 2004 & 2014 & 10 & 8 & 135 & 622 & $\mathrm{BN}$ & 2.66 & 29.3 & 142.5 & 22.4 & 132.7 & 60 & 89.6 & 7.5 \\
\hline \multirow{3}{*}{ Westfork } & 2002 & 2014 & 12 & 0 & Flat & 302 & $\mathrm{BN}$ & 2.26 & 1.5 & 4.6 & 0.3 & 1.1 & 74.4 & 61.6 & 11.7 \\
\hline & 2002 & 2014 & 12 & 0 & Flat & 319 & PM & 2.17 & 618.8 & 1.2 & 16.5 & 328.5 & 65.6 & 54.4 & 9.6 \\
\hline & 2002 & 2014 & 12 & 25 & 135 & 341 & $\mathrm{BN}$ & 2.37 & 12.8 & 86.8 & 0.1 & 151.2 & 64 & 51.2 & 12.2 \\
\hline \multirow{4}{*}{ Donnelly Flats } & 1999 & 2014 & 15 & 0 & Flat & 459 & PT & 1.67 & 18.4 & 1.5 & 54.4 & 21.4 & 88.8 & 82.4 & 3.9 \\
\hline & 1999 & 2014 & 15 & 0 & Flat & 521 & PM & 1.46 & 82.6 & 0.0 & 3.2 & 0.6 & 64 & 87.2 & 10.0 \\
\hline & 1999 & 2014 & 15 & 0 & Flat & 457 & PT & 2.44 & 31.3 & 1.0 & 108.9 & 69.0 & 64 & 80.8 & 3.6 \\
\hline & 1999 & 2014 & 15 & 0 & Flat & 477 & PT & 2.23 & 139.4 & 123.3 & 636.7 & 708.0 & 70.4 & 63.2 & 6.0 \\
\hline \multirow{4}{*}{ Hajdukovich } & 1994 & 2013 & 19 & 0 & Flat & 468 & PT & 2.61 & 8.0 & 4.4 & 26.8 & 66.7 & 84.8 & 60 & 10.2 \\
\hline & 1994 & 2013 & 19 & 0 & Flat & 456 & PT & 2.53 & 84.5 & 2.2 & 1307.4 & 179.2 & 77.6 & 45.6 & 4.2 \\
\hline & 1994 & 2013 & 19 & 0 & Flat & 466 & PT & 2.37 & 198.9 & 91.5 & 229.9 & 200.3 & 75.2 & 67.2 & 9.1 \\
\hline & 1994 & 2013 & 19 & 0 & Flat & 421 & PT & 2.72 & 155.5 & 15.8 & 242.6 & 602.3 & 77.6 & 44.8 & 7.3 \\
\hline \multirow{3}{*}{ Tok River } & 1990 & 2010 & 20 & 1 & 297 & 500 & PT & 2.89 & 28.8 & 0.0 & 1659.2 & 863.4 & 85.6 & 8 & 8.0 \\
\hline & 1990 & 2010 & 20 & 0 & Flat & 504 & PM & 1.82 & 768.3 & 1.7 & 23.6 & 54.8 & 32.8 & 54.4 & 12.4 \\
\hline & 1990 & 2010 & 20 & 0 & Flat & 503 & PT & 2.23 & 183.0 & 0.0 & 219.8 & 106.9 & 77.6 & 24 & 7.7 \\
\hline \multirow{3}{*}{ Granite Creek } & 1987 & 2008 & 21 & 1 & 54 & 385 & PT & 2.59 & 76.6 & 13.9 & 2135.8 & 141.8 & 59.2 & 20 & 3.0 \\
\hline & 1987 & 2008 & 21 & 0 & 45 & 383 & PT & 2.72 & 26.9 & 0.0 & 290.1 & 147.4 & 30.4 & 43.2 & 8.0 \\
\hline & 1987 & 2008 & 21 & 1 & 20 & 436 & PM & 1.98 & 159.2 & 0.0 & 91.4 & 132.9 & 41.6 & 26.4 & 6.0 \\
\hline \multirow{3}{*}{ Slate Creek } & 1987 & 2009 & 22 & 8 & 68 & 550 & PM & 0.21 & 276.4 & 0.0 & 0.0 & 0.3 & 36.8 & 68 & 18.8 \\
\hline & 1987 & 2009 & 22 & 5 & 64 & 572 & PT & 3 & 0.0 & 581.3 & 2820.6 & 3.2 & 88.8 & 0.8 & 2.6 \\
\hline & 1987 & 2009 & 22 & 5 & 109 & 553 & $\mathrm{BN}$ & 1.55 & 168.6 & 268.9 & 0.0 & 0.0 & 46.4 & 68.8 & 11.5 \\
\hline
\end{tabular}




\begin{tabular}{|c|c|c|c|c|c|c|c|c|c|c|c|c|c|c|c|}
\hline \multirow{3}{*}{ Rosie Creek } & 1983 & 2009 & 25 & 6 & 154 & 199 & PM & 2.57 & 174.2 & 107.1 & 0.0 & 447.1 & 58.4 & 60.8 & 16.9 \\
\hline & 1983 & 2009 & 25 & 10 & 154 & 212 & PM & 1.88 & 898.1 & 83.3 & 0.0 & 869.6 & 34.4 & 60 & 10.0 \\
\hline & 1983 & 2009 & 25 & 5 & 128 & 210 & PM & 1.53 & 595.2 & 140.9 & 0.0 & 93.5 & 49.6 & 24 & 7.8 \\
\hline \multirow{3}{*}{ Minto Flats } & 1983 & 2009 & 26 & 11 & 99 & 417 & PT & 2.91 & 12.5 & 1.0 & 1756.4 & 0.0 & 61.6 & 43.2 & 1.4 \\
\hline & 1983 & 2009 & 26 & 9 & 103 & 428 & PM & 1.18 & 56.2 & 0.7 & 0.0 & 1.1 & 48.8 & 51.2 & 6.0 \\
\hline & 1983 & 2009 & 26 & 15 & 122 & 473 & PT & 2.4 & 194.2 & 16.3 & 1482.6 & 0.0 & 76 & 23.2 & 3.6 \\
\hline \multirow{3}{*}{ Bolio } & 1981 & 2010 & 29 & 1 & 308 & 496 & PT & 2.36 & 141.3 & 0.0 & 986.8 & 17.0 & 88.8 & 34.4 & 3.2 \\
\hline & 1981 & 2010 & 29 & 2 & 301 & 507 & PT & 2.72 & 137.5 & 0.0 & 3824.6 & 0.0 & 96.8 & 18.4 & 6.4 \\
\hline & 1981 & 2010 & 29 & 2 & 301 & 496 & PM & 1.68 & 405.2 & 1.4 & 5.3 & 26.6 & 83.2 & 32.8 & 9.2 \\
\hline \multirow{7}{*}{$\begin{array}{l}\text { Wickersham Dome } \\
\text { Exp. }\end{array}$} & 1978 & 2009 & 31 & 9 & 140 & 494 & $\mathrm{BN}$ & 2.66 & 208.2 & 4508.6 & 0.0 & 464.0 & 72.8 & 16.8 & 7.4 \\
\hline & 1978 & 2009 & 31 & 9 & 124 & 494 & PM & 1.73 & 1019.4 & 554.2 & 0.0 & 761.8 & 64 & 39.2 & 5.5 \\
\hline & 1978 & 2009 & 31 & 8 & 130 & 522 & PT & 1.97 & 219.9 & 0.0 & 3407.5 & 378.0 & 76 & 25.6 & 3.8 \\
\hline & 1978 & 2009 & 31 & 12 & 87 & 515 & PT & 2.16 & 347.5 & 90.1 & 505.2 & 508.8 & 43.2 & 53.6 & 4.0 \\
\hline & 1978 & 2009 & 31 & 8 & 108 & 521 & PM & 1.2 & 304.2 & 1.9 & 0.0 & 116.2 & 44.8 & 44.8 & 9.4 \\
\hline & 1978 & 2009 & 31 & 10 & 108 & 509 & PM & 1.17 & 482.1 & 33.1 & 1.1 & 247.5 & 23.2 & 53.6 & 6.6 \\
\hline & 1978 & 2009 & 31 & 7 & 105 & 537 & $\mathrm{BN}$ & 2.46 & 190.1 & 486.8 & 34.3 & 282.5 & 67.2 & 47.2 & 5.0 \\
\hline \multirow{3}{*}{ Wickersham Dome } & 1971 & 2010 & 37 & 1 & 203 & 526 & PM & 0.49 & 469.2 & 0.0 & 0.0 & 17.6 & 47.2 & 42.4 & 7.2 \\
\hline & 1971 & 2010 & 37 & 11 & 176 & 483 & PT & 2.61 & 454.7 & 105.5 & 4110.3 & 33.9 & 92 & 5.6 & 7.0 \\
\hline & 1971 & 2010 & 37 & 11 & 235 & 403 & $\mathrm{BN}$ & 1.19 & 403.6 & 693.5 & 0.0 & 14.5 & 50.4 & 56.8 & 10.6 \\
\hline \multirow{5}{*}{ Big Denver } & 1969 & 2008 & 39 & 0 & 234 & 125 & PM & 1.39 & 2187.2 & 0.0 & 925.3 & 75.2 & 50.4 & 36.8 & 6.0 \\
\hline & 1969 & 2008 & 39 & 0 & 192 & 136 & PT & 2.04 & 419.9 & 0.0 & 2852.5 & 71.3 & 81.6 & 10.4 & 5.0 \\
\hline & 1969 & 2008 & 40 & 8 & 160 & 221 & $\mathrm{BN}$ & 3 & 0.0 & 10528.6 & 0.0 & 583.7 & 97.6 & 3.2 & 2.8 \\
\hline & 1969 & 2008 & 40 & 7 & 255 & 269 & PM & 2.13 & 2696.0 & 2030.1 & 0.0 & 821.2 & 84 & 49.6 & 12.0 \\
\hline & 1969 & 2008 & 41 & 5 & 206 & 345 & PT & 2.59 & 157.5 & 39.0 & 5357.4 & 309.1 & 93.6 & 18.4 & 4.6 \\
\hline \multirow{2}{*}{ Goldstream } & 1966 & 2009 & 43 & 1 & 38 & 144 & PM & 1.7 & 3223.2 & 1973.2 & 0.0 & 573.8 & 67.2 & 47.2 & 8.6 \\
\hline & 1966 & 2009 & 43 & 3 & 276 & 144 & PM & 1.87 & 2938.0 & 0.0 & 0.0 & 1287.2 & 64.8 & 71.2 & 15.0 \\
\hline Chena Dome & 1958 & 2009 & 50 & 3 & 145 & 229 & PM & 0.94 & 2168.0 & 0.0 & 0.0 & 250.7 & 16.8 & 87.2 & 14.0 \\
\hline Healy & 1958 & 2008 & 50 & 6 & 149 & 642 & PM & 1.53 & 3873.9 & 1483.6 & 1323.6 & 43.8 & 48 & 84 & 7.4 \\
\hline \multirow{3}{*}{ Murphy Dome } & 1958 & 2009 & 51 & 7 & 45 & 208 & $\mathrm{BN}$ & 2.99 & 0.0 & 11614.5 & 0.0 & 0.0 & 93.6 & 3.2 & 4.6 \\
\hline & 1958 & 2009 & 51 & 6 & 53 & 197 & $\mathrm{BN}$ & 1.99 & 2844.8 & 8613.2 & 0.0 & 0.0 & 87.2 & 41.6 & 13.8 \\
\hline & 1958 & 2009 & 51 & 6 & 11 & 200 & PM & 1.1 & 959.2 & 24.4 & 0.0 & 3.6 & 45.6 & 93.6 & 23.2 \\
\hline \multirow{2}{*}{ Sawtooth Mountain } & 1957 & 2009 & 52 & 4 & 286 & 502 & PM & 1.7 & 1520.5 & 557.6 & 1387.6 & 230.7 & 74.4 & 51.2 & 5.2 \\
\hline & 1957 & 2009 & 52 & 4 & 213 & 489 & PM & 1.28 & 1683.0 & 106.3 & 86.2 & 151.8 & 52 & 28.8 & 4.0 \\
\hline \multirow{3}{*}{ Big Gerstle } & 1947 & 2009 & 62 & 1 & 3 & 493 & $\mathrm{BN}$ & 1.94 & 1265.7 & 7055.2 & 1824.2 & 1201.7 & 91.2 & 20.8 & 4.0 \\
\hline & 1947 & 2009 & 62 & 1 & 344 & 506 & PT & 2.49 & 17.2 & 3020.1 & 9601.5 & 337.7 & 84 & 32.8 & 2.4 \\
\hline & 1947 & 2009 & 62 & 2 & 15 & 535 & PM & 1.58 & 765.0 & 195.1 & 0.0 & 35.0 & 37.6 & 61.6 & 17.8 \\
\hline Mature deciduous 4 & NA & 2009 & 70 & 4 & 135 & 288 & $\mathrm{BN}$ & 2.65 & 514.7 & 13456.3 & 0.0 & 1522.8 & 96.8 & 0 & 14.6 \\
\hline Mature deciduous 2 & NA & 2009 & 74 & 4 & 135 & 433 & $\mathrm{BN}$ & 2.4 & 0.0 & 9388.5 & 0.0 & 74.2 & 96 & 0 & 7.8 \\
\hline Mature spruce 1 & NA & 2009 & 78 & 9 & 20 & 400 & PM & 1.44 & 2695.9 & 297.0 & 0.0 & 48.7 & 39.2 & 96 & 27.8 \\
\hline Mature deciduous 1 & NA & 2009 & 84 & 5 & 90 & 489 & PT & 2.78 & 4.0 & 0.0 & 10391.8 & 0.0 & 91.2 & 17.6 & 4.5 \\
\hline Mature spruce 4 & NA & 2009 & 85 & 5 & 54 & 270 & PM & 0 & 5127.8 & 0.0 & 0.0 & 0.0 & 31.2 & 96 & 24.0 \\
\hline Mature deciduous 3 & NA & 2009 & 87 & 4 & 135 & 265 & $\mathrm{BN}$ & 3 & 0.0 & 19949.1 & 0.0 & 93.6 & 95.2 & 13.6 & 9.0 \\
\hline Mature deciduous 5 & NA & 2009 & 120 & 6 & 11 & 519 & PT & 2.67 & 12.1 & 0.0 & 12712.6 & 111.9 & 88.8 & 44.8 & 4.4 \\
\hline Mature spruce 3 & NA & 2009 & 138 & 0 & 0 & 485 & PM & 0 & 4906.9 & 0.0 & 0.0 & 0.0 & 12.8 & 98.4 & 28.6 \\
\hline Mature spruce 2 & NA & 2009 & 163 & 0 & 0 & 480 & PM & 1.62 & 6585.0 & 0.0 & 0.0 & 52.9 & 48 & 86.4 & 25.4 \\
\hline
\end{tabular}


$4 \quad{ }^{1}$ Years since fire (age) based on sampling year minus year burned from historic fire records, or tree rings in the case of some of the oldest stands.

$5 \quad{ }^{2}$ Forest type based on the dominant contribution to total standing biomass. See Alexander et al. (2012) for calculation.

$6 \quad{ }^{3}$ Deciduous Importance Value (IV). See Alexander et al. (2012) for calculation.

$7 \quad{ }^{4}$ Estimated from density and basal area using allometric equations presented in Alexander et al. (2012).

$8{ }^{5}$ Estimated from density and basal area of large shrubs (Alnus spp., Salix spp. and Betula spp.) using allometric equations in Berner et al. (2015). 
11 Supplementary Table S2: Results from the two-way ANOVA on total bryophyte cover compared

12 between the three forest types (black spruce, Alaskan paper birch, and trembling aspen) and the

13 three post-fire successional periods (early, mid-, and late succession). This ANOVA used a type

14 III sums of squares in $\mathrm{R}$ to address the unbalanced data.

\begin{tabular}{lcccc}
\hline & Sum of squares & $\begin{array}{c}\text { Degrees of } \\
\text { freedom }\end{array}$ & F value & $p$ \\
\hline Forest type & 137 & 2 & 0.236 & 0.791 \\
Successional & 12414 & 2 & 21.345 & $<0.0001 *$ \\
stage & 10836 & 4 & 9.316 & $<0.0001 *$ \\
Interaction & 21519 & 74 & & \\
Residuals & & &
\end{tabular}

16 
17 Supplementary Table S3: Results from the two-way unbalanced ANOVAs by permutation

18 (4999) conducted on the three major bryophyte functional groups compared between the three

19 forest types (black spruce, Alaskan paper birch, and trembling aspen) and the three post-fire

20 successional periods (early, mid-, and late succession). This ANOVA used a type III sums of

21 squares in $\mathrm{R}$ to address the unbalanced data.

22 a) Colonizers

\begin{tabular}{lcccc}
\hline & Mean squares & $\begin{array}{c}\text { Degrees of } \\
\text { freedom }\end{array}$ & F statistic & $p$ \\
\hline Forest type & 1.494 & 2 & 0.251 & 0.7776 \\
$\begin{array}{l}\text { Successional } \\
\text { stage }\end{array}$ & 545.229 & 2 & 91.435 & $0.0002^{*}$ \\
Interaction & 2.834 & 4 & 0.916 & 0.9154 \\
Residuals & 220.632 & 74 & & \\
\hline
\end{tabular}

23

24

b) Feather mosses

\begin{tabular}{lcccc}
\hline & Mean squares & $\begin{array}{c}\text { Degrees of } \\
\text { freedom }\end{array}$ & F statistic & $\boldsymbol{p}$ \\
\hline Forest type & 53.545 & 2 & 14.272 & $<0.0001^{*}$ \\
$\begin{array}{l}\text { Successional } \\
\text { stage }\end{array}$ & 86.584 & 2 & 23.079 & $<0.0001^{*}$ \\
Interaction & 75.869 & 4 & 10.111 & $<0.0001^{*}$ \\
Residuals & 138.810 & 74 & & \\
\hline
\end{tabular}

25

26

\begin{tabular}{|c|c|c|c|c|}
\hline & Mean squares & $\begin{array}{l}\text { Degrees of } \\
\text { freedom }\end{array}$ & F statistic & $p$ \\
\hline Forest type & 20.517 & 2 & 10.460 & $0.0014 *$ \\
\hline $\begin{array}{l}\text { Successional } \\
\text { stage }\end{array}$ & 0.159 & 2 & 0.081 & 0.9248 \\
\hline Interaction & 0.631 & 4 & 0.161 & 0.9488 \\
\hline Residuals & 72.573 & 74 & & \\
\hline
\end{tabular}


46

47

Supplementary Table S4: Results from the two-way unbalanced ANOVA on taxa composition data compared between the three forest types (black spruce, Alaskan paper birch, and trembling aspen) and the three post-fire successional periods (early, mid-, and late succession).

a) Results from the 2 way unbalanced ANOVA with permutations (4999) on taxa composition data. Similar results were obtained by using a Hellinger transformation on species data, or using a permutation ANOVA with Bray-Curtis distance not accounting for unbalanced data.

\begin{tabular}{lcccc}
\hline & $\begin{array}{c}\text { Degrees of } \\
\text { freedom }\end{array}$ & Variance & F statistic & $\boldsymbol{p}$ \\
\hline Forest type & 2 & 93.71 & 3.729 & $0.0006^{*}$ \\
Successional & 2 & 438.75 & 17.461 & $0.0002^{*}$ \\
stage & 4 & 110.28 & 2.194 & $0.0030^{*}$ \\
Interaction & 74 & 929.72 & & \\
Residuals & & & & \\
\hline
\end{tabular}

b) ANOVA by permutations (4999) comparing bryophyte taxa composition among forest types within the early succession stands.

\begin{tabular}{lcccc}
\hline & $\begin{array}{c}\text { Degrees of } \\
\text { freedom }\end{array}$ & Sum of squares & F statistic & $\boldsymbol{p}$ \\
\hline Forest type & 2 & 0.443 & 1.888 & 0.0572 \\
Residuals & 26 & 3.049 & & \\
Total & 28 & 3.491 & & \\
\hline
\end{tabular}

c) ANOVA by permutations (4999) comparing bryophyte taxa composition among forest types within the mid-succession stands, followed by pairwise comparisons using the Bonferonni correction for multiple comparisons.

\begin{tabular}{lcccc}
\hline & $\begin{array}{c}\text { Degrees of } \\
\text { freedom }\end{array}$ & Sum of squares & F statistic & $p$ \\
\hline Forest type & 2 & 1.394 & 2.848 & $0.0004^{*}$ \\
Residuals & 39 & 9.542 & & \\
Total & 41 & 10.935 & & \\
\hline
\end{tabular}

\begin{tabular}{lcc}
\hline $\begin{array}{c}\text { Post hoc pairwise } \\
\text { comparisons }\end{array}$ & F statistic & $\begin{array}{c}\text { Adjusted } \\
\boldsymbol{p}\end{array}$ \\
\hline Spruce vs. Aspen & 4.171 & $0.009^{*}$ \\
Spruce vs. Birch & 1.506 & 0.471 \\
Aspen vs. Birch & 2.306 & 0.141 \\
\hline
\end{tabular}


d) ANOVA by permutations (4999) comparing bryophyte taxa composition among forest types within the late succession stands, followed by pairwise comparisons using the

50 Bonferonni correction for multiple comparisons.

\begin{tabular}{lcccc}
\hline & $\begin{array}{c}\text { Degrees of } \\
\text { freedom }\end{array}$ & Sum of squares & F statistic & $p$ \\
\hline Forest type & 2 & 4.429 & 4.298 & $0.0008^{*}$ \\
Residuals & 9 & 1.497 & & \\
Total & 11 & 2.916 & & \\
\hline
\end{tabular}

51

\begin{tabular}{lcc}
\hline $\begin{array}{c}\text { Post hoc pairwise } \\
\text { comparisons }\end{array}$ & F statistic & $\begin{array}{c}\text { Adjusted } \\
\boldsymbol{p}\end{array}$ \\
\hline Spruce vs. Aspen & 3.849 & 0.153 \\
Spruce vs. Birch & 5.785 & 0.030 \\
Aspen vs. Birch & 2.601 & 0.585 \\
\hline
\end{tabular}

52

53

54

55

56

57

58 